\title{
Wage Inequality in Germany: Disentangling Demand and Supply Effects
}

\author{
Michael Stimmelmayr
}

CESIFO WORKING PAPER NO. 2802

CATEGORY 4: LABOUR MARKETS

SEPTEMBER 2009

\footnotetext{
An electronic version of the paper may be downloaded

- from the SSRN website: Www.SSRN.com

- from the RePEc website: $\quad$ www.RePEc.org

- from the CESifo website: www.CESifo-group.org/wp
} 


\title{
Wage Inequality in Germany: Disentangling Demand and Supply Effects
}

\begin{abstract}
In this paper we conduct a counterfactual analysis and estimate the quantitative importance of demand and supply effects on wage inequality in Germany using a dynamic computable general equilibrium (CGE) model of the Auerbach-Kotlikoff (1987) type. Specifically, the methodological contribution of our dynamic CGE model refers to the three-level constant elasticity of substitution production function and the endogenous labor supply of three different skill types, which enable us to isolate the impact of capital-skill complementarity (i.e., demand effects) and varying skill-specific labor supply (i.e., supply effects) on the evolution of the skill premia as defined by the 9 th to $1 \mathrm{st}$, the 9 th to 5 th, and the 5 th to $1 \mathrm{st}$ decile limit of earnings.

In short, our simulation results show that the complementarity effect has a particularly strong positive impact on the skill premium of the high-skilled, while the quantity effect counteracts the complementarity effect and exerts an alleviating pressure on the skill premium of the high-skilled. In quantitative terms, the complementarity effect raises the skill premium of the 9th to 1 st and the 9th to 5th decile limit of earnings by more than 1.0 and 0.8 percent per year, respectively. By contrast, the quantity effect reduces both above-mentioned skill premia by almost 0.3 and 0.45 percent per year, respectively. Even though the complementarity and the quantity effects work in opposite directions, the complementarity effect has a much stronger impact on the skill premia of the high-skilled compared with the quantity effect.
\end{abstract}

JEL Code: J31, J23, C68.

Keywords: capital-skill complementarity, skill premium, wage inequality, skill-specific labor supply, dynamic general equilibrium analysis.

Michael Stimmelmayr
Center for Economic Studies at the University of Munich
Schackstrasse 4
Germany-80539 Munich
stimmelmayr@Imu.de

September 2009

I am particularly grateful for the comments by Christian Bayer and all other seminar participants at the XIII Spring Meeting of Young Economists (SMYE) 2008. In addition I thank the seminar participants at the International Conference on Policy Modeling (EcoMod) 2008 and at the XIV Annual Meetings of the Society of Labor Economists (SOLE) 2009. 


\section{Introduction}

After the slowdown of the German economy in 2001, the earnings dispersion, measured by the ratio of the $9^{\text {th }}$ to $1^{\text {st }}$ decile limit of earnings, increased substantially (Gernandt and Pfeiffer, 2006). As reported by the OECD Employment Outlook 2007, the earnings dispersion over the period from 1995 to 2005 increased by 12.2 percent in Germany but only by 5.9 percent in the United States, or Sweden, and by less than 1 percent in the United Kingdom or France. Despite this enormous hike in earnings inequality, Germany also faced a steady increase in the supply of highly educated workers during the same period. Between 1991 and 2005 the number of German citizens holding a university degree rose by more than 13 percent (Destatis 1994, 2006). Therefore, Germany showed the same puzzling pattern of rising earnings inequality during a period of substantial growth in the supply of high-skilled workers, as previously observed in the United States and elsewhere ${ }^{1}$ (for example, see Bound and Johnson 1992, Katz and Murphy 1992, Krussel et al. 2000, or Lindquist 2005). ${ }^{2}$

We approach this puzzle and disentangle the quantitative importance of demand and supply effects by applying a dynamic computable general equilibrium (CGE) model in the spirit of Auerbach-Kotlikoff (1987). The CGE model is embedded in the framework of a neoclassical growth model and features a three-level constant elasticity of substitution (CES) production function with capital and three different skill types of labor as input factors. Both the firm's and the household's behavior are forward-looking. The firm's optimal investment and skillspecific labor demand are derived from an intertemporal investment model while the household maximizes its lifetime utility via an optimal intertemporal consumption path and optimal skillspecific labor supply.

The methodological innovation of our dynamic CGE model refers to the three-level CES production function using capital, and low-, medium-, and high-skilled labor as input factors, and to the endogenous labor supply of these three skill types. Given this set-up, the CGE model enables us to isolate the quantitative importance of capital-skill complementarity and varying skill-specific labor supply on the evolution of the skill premia as defined by the $9^{\text {th }}$ to $1^{\text {st }}$, the $9^{\text {th }}$ to $5^{\text {th }}$, and the $5^{\text {th }}$ to $1^{\text {st }}$ decile limit of earnings. This distinction between the repercussions resulting from the complementarity effect (i.e., the demand effects) and the quantity effect (i.e., the supply effects) constitutes an important contribution of our work to the literature on wage inequality that has been largely neglected in the past. Furthermore, the CGE model enables us to provide profound estimates for the substitution elasticities between capital and the different labor skill types, as done in the empirical studies, for instance, by Krussel et al. (2000) or Lindquist (2005). In addition, we simultaneously derive adequate labor supply elasticities for the different skill groups under the presence of capital-skill complementarity that

\footnotetext{
${ }^{1}$ The hypothesis of capital-skill complementarity was first formalized by Griliches (1969) and states that the elasticity of substitution between capital and unskilled labor is higher than the one between capital and highskilled labor. A stronger version of this hypothesis even predicts that capital and unskilled labor are substitutes in production while capital and high-skilled labor are complements. As a consequence of this hypothesis, the skill premium tends to increase whenever capital is accumulated. Contrary to that, the steady increase in the relative supply of skilled vis-à-vis unskilled labor should have an alleviating impact on the skill premium and thus on wage inequality. The rationale refers to the cost advantage of skilled vis-à-vis unskilled labor, if the former is more elastically supplied compared with the latter.

2 The capital-skill complementarity hypothesis has been the subject of numerous empirical studies such as, for example, Griliches (1969), Fallon and Layard (1975), Bound and Johnson (1992), Goldin and Katz (1998), or Lindquist (2005). For cross-country evidence see Machin and Van Reenen (1998), Duffy et al. (2003), or Papageorgiou and Chmelarova (2005).
} 
are consistent with the actual pattern in German skill premia and skill-specific labor supply in Germany. Finally, the fact that we also account for medium-skilled labor in addition to lowand high-skilled labor is another important feature that separates our work from the existing papers in this strand of the literature. ${ }^{3}$ The group of medium-skilled workers is, however, of particular importance when analyzing wage inequality (in Germany), since medium-skilled labor often accounts for the largest share of the total labor force (about 58 percent in Germany), while low- and high-skilled workers are much less important in quantitative terms (they account for about 15 and 27 percent of the labor force, respectively, in Germany). Hence, the aggregation of medium-skilled labor together with either low- or high-skilled labor creates major inconsistencies and biased estimates, which are not consistent with the empirical data on macro aggregates.

Our simulation results confirm our conjecture and show that the complementarity effect has a particularly strong positive impact on the skill premium of the high-skilled, while the quantity effect counteracts the complementarity effect and exerts an alleviating pressure on the skill premium of the high-skilled. In quantitative terms, the complementarity effect raises the skill premium of the $9^{\text {th }}$ to $1^{\text {st }}$ and the $9^{\text {th }}$ to $5^{\text {th }}$ decile limit of earnings by more than 1.0 and 0.8 percent per year, respectively. The quantity effect, on the other hand, reduces both abovementioned skill premia by almost 0.3 and 0.45 percent per year, respectively. With regard to the skill premium defined by the $5^{\text {th }}$ to $1^{\text {st }}$ decile limit of earnings, the complementarity and the quantity effects are not antagonists, but work in the same direction. The complementarity effect causes a yearly increase of 0.22 percent in the skill premium of the $5^{\text {th }}$ to $1^{\text {st }}$ decile limit of earnings while the quantity effect causes an increase of 0.18 percent per year. Moreover, we find that the less elastic the labor supply elasticities are, the larger the impact of capital-skill complementarity on skill premia.

Even though the complementarity and the quantity effects work in general in the opposite direction, the complementarity effect has a much stronger - about 2.5 times larger - impact on skill premia of the high-skilled as compared with the impact of the quantity effect.

The remainder of this paper is structured as follows. The next section introduces the theoretical setup of the dynamic CGE model and outlines the three-level CES production function as well as the optimal labor supply of households. It additionally covers the calibration and empirical implementation of the model. Section 3 presents the conducted simulations with regard to the complementarity and the quantity effect as well as several sensitivity analyses, while Section 4 concludes.

\section{Theoretical Setup and Calibration}

In the spirit of Auerbach and Kotlikoff (1987) we develop a dynamic, two-country CGE model based on neoclassical growth theory. ${ }^{4}$ The representative firm's optimal behavior is derived by an intertemporal investment model with convex adjustment costs. The three-level CES production function features capital-skill complementarity and uses low-, medium-, and high-skilled labor, next to capital, as input factors. On the household side, a representative, infinitively lived

\footnotetext{
${ }^{3}$ Nearly all papers in the existing literature distinguish only between low- and high-skilled labor but neglect medium-skilled labor when explaining wage inequality. See, for instance, Bound and Johnson (1992), Duffy et al. (2003), Goldin and Katz (1998), Krussel et al. (2000), Lindquist (2005), Papageorgiou and Chme- larova (2005), or Topel (1997).

${ }^{4} \mathrm{~A}$ comprehensive model documentation is provided by Stimmelmayr (2007).
} 
individual maximizes his lifetime utility via an optimally chosen intertemporal consumption path and optimal skill-specific labor supply.

Our dynamic CGE model thus mimics the most important behavioral margins at the firm and household levels that influence the evolution of the skill premia measured by the $9^{t h}$ to $1^{s t}$, the $9^{\text {th }}$ to $5^{\text {th }}$, and the $5^{\text {th }}$ to $1^{\text {st }}$ decile limit of earnings, respectively. Since capital accumulation and labor supply are dynamic phenomena, the applied model is especially suitable for quantifying the impact of economic growth on the skill premium under the presence of both capital-skill complementarity and a varying relative supply of the different labor skill types. ${ }^{5}$

One important limitation of our model is the fact that there is no scope for "involuntary" unemployment in general equilibrium since labor markets are assumed to be competitive and no constraints are imposed on the behavior of firms or workers.

Moreover, as frequently discussed, any increase in the skill premium provides an incentive to invest in human capital. Even though the model does not explicitly feature the household's investment in human capital, we solve this shortcoming by applying differentiated supply elasticities for the various skill types of labor. ${ }^{6}$

\subsection{Production Technology}

The representative firm relies on a neoclassical, well-behaved, linearly homogenous three-level CES production technology, $Y=F\left(K, L^{L}, L^{M}, L^{H}\right)$ with capital, $K$, low-skilled, $L_{L}$, mediumskilled, $L_{M}$, and high-skilled labor, $L_{H}$, as input factors

$$
\begin{aligned}
Y=F\left(K, L_{L}, L_{M}, L_{H}\right) & =F_{K} K+F_{L_{L}} L_{L}+F_{L_{M}} L_{M}+F_{L_{H}} L_{H}, \\
\text { with } \quad F(0) & =0 ; \quad F^{\prime}>0 ; \quad F^{\prime \prime}<0 .
\end{aligned}
$$

The respective wage rates of each labor skill type are denoted by $w^{i}$, with $i \in\{L, M, H\}$. The price of the output good is normalized to unity. Investments, $I$, incur adjustment costs of size $J(I, K)$, which imply decreasing returns from capital accumulation. ${ }^{7}$ Accounting for total wage costs, $\sum w_{i} L_{i}$, and depreciation of capital, $\delta K$, the profits of the representative firm are given by

$$
\pi=Y_{t}-J_{t}-\sum w_{i, t} L_{i, t}-\delta K_{t}
$$

\section{Capital-Skill Complementarity}

The feature of capital-skill complementarity is embedded in the three-level CES production function by the means of nested CES aggregates and varying elasticities of substitution on each level. Our specification of the production function states

$$
\tilde{Y}=\Upsilon^{1}\left\{L_{L}, \Upsilon^{2}\left[L_{M}, \Upsilon^{3}\left(K, L_{H}\right)\right]\right\},
$$

with $\Upsilon^{1}, \Upsilon^{2}$ and $\Upsilon^{3}$ representing CES aggregates. According to GRILICHES (1969), the feature of capital-skill complementarity just requires the elasticity of substitution within the CES aggregate

\footnotetext{
${ }^{5}$ Compared with a simple steady-state analysis, our dynamic CGE model traces the economy's complete phase of transition from the initial to the final steady state.

${ }^{6}$ Additionally, we perform several sensitivity analyses with regard to the applied labor supply elasticities that enable us to map the pattern in labor supply of the different skill types as reported in the German data.

${ }^{7}$ The adjustment cost function, $J(I, K)$ is linearly homogeneous in investments, $I$, and capital, $K$, and convex in investments, $J_{I}$ and $J_{I I}>0$. Moreover, steady-state adjustment costs are zero.
} 
$\Upsilon^{3}$ to be the smallest, but it imposes no further restrictions on the absolute or relative size of the substitution elasticity between medium-skilled labor and the capital-skill input, $\Upsilon^{3}\left(K, L_{H}\right)$, or the one between low-skilled labor and the intermediate input, $\Upsilon^{2}\left(L_{M}, \Upsilon^{3}\right){ }^{8}$

The reader might wonder why we apply a three-level CES production function in our CGE model while mostly two-level CES functions are applied in the (empirical) literature. If we rely on a simple two-level production technology, we would have to include medium-skilled labor either together with low-skilled labor or together with high-skilled labor in one nest. Such a modeling approach, however, is not consistent with the empirical data on German macro aggregates and would thus reduce our model's fit substantially. This problem arises because medium-skilled labor constitutes the lion's share of total labor supply in the German economy, and accordingly, lumping the quantitatively important magnitude of medium-skilled labor together with low- or high-skilled labor, respectively, causes substantial inconsistencies. Moreover, under a two-level production technology we are not able to track the evolution of the skill premia of the $9^{\text {th }}$ to $5^{\text {th }}$ and the $5^{\text {th }}$ to $1^{\text {st }}$ decile limit of earnings because changes in factor demands reveal to be proportional within each nest.

Given the specification of the production technology in (3), the functional form of the production function becomes

$$
Y=\left\{\alpha_{L} L_{L}^{-\rho_{1}}+\gamma_{L}\left[\alpha_{M} L_{M}^{-\rho_{2}}+\gamma_{M} A^{-\rho_{2}}\left(\alpha_{H} L_{H}^{-\rho_{3}}+\gamma_{H} K^{-\rho_{3}}\right)^{-\frac{\rho_{2}}{\rho_{3}}}\right]^{-\frac{\rho_{1}}{\rho_{2}}}\right\}^{-\frac{1}{\rho_{1}}}
$$

with $\gamma_{i}=\left(1-\alpha_{i}\right)$ and $i \in\{L, M, H\}$. The variable $\alpha_{i}$ governs the distribution parameter of the production function and the variable $A$ denotes neutral technological change while the variable $\rho_{i}$ with $i \in\{L, M, H\}$ denotes the substitution parameter between the input factors. The respective substitution elasticities are defined by $\sigma_{i}=1 /\left(1+\rho_{i}\right)$ with $i \in\{L, M, H\}^{9}$. As discussed above, the feature of capital-skill complementarity just requires $\sigma_{H}$ to be the smallest elasticity within the production function but places no further restriction on the substitution elasticities. $^{10}$

In the case where we abstract from capital-skill complementarity we set all substitution elasticities to one in our simulations.

\footnotetext{
${ }^{8}$ Another way of modeling capital-skill complementarity using a three-level CES function is to place lowskilled labor and capital together in one nest, similar to $\hat{Y}=\Upsilon^{1}\left\{L_{H}, \Upsilon^{2}\left[L_{M}, \Upsilon^{3}\left(K, L_{L}\right)\right]\right\}$. Such a specification, however, requires an identical substitution elasticity between high-skilled labor and capital, and high-skilled labor and low-skilled labor, which, according to Hammermesh's 1993 findings, is not true.

${ }^{9}$ Specifically, the elasticity of substitution between high-skilled labor and capital is given by $\sigma_{H}$, the one between medium-skilled labor and the capital-kill input by $\sigma_{M}$ and finally the one between low-skilled labor and the intermediate input by $\sigma_{L}$.

${ }^{10}$ In case low-skilled labor and capital are assumed to be substitutes while high-skilled labor and capital are complements, the substitution elasticities and substitution parameters have the following properties: $\sigma_{L}>1$ with $1<\rho_{L}<\infty$ and $\sigma_{H}<1$ with $-1<\rho_{H}<0$.
} 


\section{Firm Value and Optimal Firm Behavior}

The firm value, $V_{t}$, is determined by the present value of all future payouts, $\chi$, which are residually determined by net of tax profits less investment expenditures

$$
\begin{aligned}
V_{t}= & \sum_{S=t}^{\infty} \frac{\chi_{S}}{1+r_{S}^{V}} \prod_{z=t}^{S+1} \frac{G}{1+r_{Z}^{V}}, \\
\text { with } \quad & \chi_{t}=(1-\tau)\left[Y_{t}-J_{t}-\sum w_{i, t} L_{i, t}-\delta K_{t}\right]-I_{t} .
\end{aligned}
$$

The variable $G$ represents the steady-state growth factor, $1+g$, and the discount rate $r^{V}$ denotes the return on firm equity. Optimal firm behavior follows from the firm's maximization problem

$$
\begin{aligned}
V_{t}\left(K_{t}\right)=\max _{L_{i, t}, I_{t}, i \in\{L, M, H\}} & {\left[\chi_{t}+\frac{G}{1+r_{t+1}^{V}} V\left(K_{t+1}\right)\right], } \\
\text { s.t. } & G K_{t+1}=I_{t}+(1-\delta) K_{t},
\end{aligned}
$$

and yields the following first-order conditions:

$$
\begin{aligned}
& \text { (a) } L_{i}: \quad F_{L_{i}, t}=w_{t}^{i}, \\
& \text { (b) } I: q_{t+1}^{e}=\left(1+r_{t+1}^{V}\right)\left[1+J_{I}\right]
\end{aligned}
$$

Following (7a), the optimal labor demand for each skill type is determined by the point of equality between the marginal product of the respective labor skill type, $F_{L_{i}}$, and its corresponding wage rate, $w^{i}$.

Optimal investment behavior, as specified in (7b), requires that the shadow price of capital, $q_{t+1}^{e}$, equals the incurred cost of an additional investment. The latter includes acquisition and adjustment costs.

\subsection{Household Side and Labor Supply}

The household sector is modeled in the spirit of an infinitely lived, representative agent whose maximization problem involves the optimal intertemporal choice of consumption, $C$, and the optimal individual labor supply of each skill category $l_{i}, i \in\{L, M, H\}$. The rate of time preference, $\rho$, determines the weight the household assigns to future consumption. Additionally, labor supply involves some disutility of work of size $\varphi\left(l_{i}\right)$. Starting with these ingredients the household's maximization problem states

$$
\begin{aligned}
U\left(A_{t}\right)=\max _{C_{t}, l_{i, t}} \max _{i \in\{, M, H\}}\left[u\left(C_{t}-\sum_{i}^{3} \varphi\left(l_{i, t}\right)\right)+\rho U^{*}\left(A_{t+1}^{H}\right)\right], \\
\text { s.t. } \quad G A_{t+1}=\left(1+r_{t}^{V}\right) A_{t}+\sum_{i}^{3}\left[w_{t, i} L_{t, i}\right]-C_{t} .
\end{aligned}
$$

The total wealth of the representative household consists of his capital endowment, $A$, his capital income, $r^{V} A$, earned on corporate equity, and the sum of labor income, $\sum_{i}^{3}\left[w_{t, i} L_{t, i}\right]$, earned by each skill type of labor supplied. The optimal labor supply of each respective skill type requires the marginal disutility from labor supply to equal the compensation payment received via wages

$$
\varphi^{\prime}\left(l_{i}\right)=w_{i} .
$$


Applying a specific functional form for the disutility of work that is contingent on the respective labor supply elasticity, $\varepsilon_{i}$, and a scaling parameter, $\xi$, the individual labor supply of each skill category reads ${ }^{11}$

$$
\varphi\left(l_{i}\right)=\xi^{-1 / \varepsilon_{i}} \frac{l^{1+1 / \varepsilon_{i}}}{1+1 / \varepsilon_{i}} \quad=>\quad l_{i, t}=\xi\left[w_{i}\right]^{\varepsilon_{i}} .
$$

Finally, the household's optimal consumption path is determined by the Euler Equation

$$
\frac{u^{\prime}\left(Q_{t}\right)}{u^{\prime}\left(Q_{t+1}\right)}=\frac{\rho\left(1+r_{t+1}^{V}\right)}{G}, \quad \text { with } Q_{t}=C_{t}-\sum_{i}^{3} \varphi\left(l_{i, t}\right)
$$

which specifies the marginal rate of substitution between present and future consumption.

\subsection{Empirical Implementation of the CGE Model}

The computational procedure of any numeric CGE model requires the specification of functional forms and the choice of appropriate behavioral parameters and elasticities from the empirical literature. In this context, the calibration implies that the model's initial steady state replicates the stationary long-run macroeconomic equilibrium of the considered economy. ${ }^{12}$ All behavioral parameters applied in our model are standard results in line with the empirical literature. The most important behavioral parameters applied are summarized in Table 1.

The real annual growth rate of the German economy is assumed to be 1.1 percent, which is, according to Bandholz et al. (2005), a fair estimate for Germany after reunification. Economic depreciation is set to 5 percent of the capital stock.

The adjustment speed towards the new steady state is determined by the half-life of investment. As in the study of Cummins et al. (1996), we take a value of 8.0, which implies that during the following eight years after a shock half of the long-run increase in the capital stock is accumulated. ${ }^{13}$

Table 1: Behavioral Parameter Values Applied

\begin{tabular}{lr}
\hline \hline Annual German Growth Rate (BANDHOLZ et al., 2005) & 0.011 \\
Half-life of Capital Accumulation (Cummins et al., 1996) & 8.0 \\
Elasticity of Substitution between & \\
$\quad$ high-skilled labor and capital (LiNDQUiST, 2005) & 0.51 \\
$\quad$ medium-skilled labor and capital-skill input & 1.33 \\
$\quad$ low-skilled labor and intermediate input & 2.1 \\
Compensated labor Supply Elasticity & \\
$\quad$ low-, medium-, high-skilled & $0.89 / 0.25 / 0.8$ \\
Intertemporal Elasticity of Substitution (FLAIG 1988) & 0.40 \\
\hline \hline
\end{tabular}

One of the key parameters describing the production side of the economy is the elasticity of substitution between capital and the different skill types of labor. Most estimates for the

\footnotetext{
${ }^{11}$ Aggregate labor supply of each skill category, $L_{i}^{S}$, is achieved via aggregation: $L_{i, t}^{S}=l_{i, t} \cdot N_{t}$, where $N$ denotes the size of the labor force in the economy.

${ }^{12}$ Even though hardly any model is in the position to replicate a country's macroeconomic aggregates as detailed as depicted in the national accounts, each model should at least reflect the stylized facts of the considered economy.

${ }^{13}$ Accordingly, we set the parameter specifying adjustment costs equal to 2 . A similar value is also applied by Valkonen (1999) and represents a lower end value of available estimates (see Whited, 1994).
} 
substitution elasticity between capital and labor range between 0 and 1, depending on the underlying estimation technique. The study by Chirinko, Fazzari and Meyer (1999), for instance, suggests an elasticity of 0.25 using panel data, whereas a higher value of 0.7 is calculated by Jorgenson and Yun (2001).

Those studies that estimate substitution elasticities in the presence of capital-skill complementarity, such as that by Krussel et al. (2000) or Lindquist (2005), find substantially larger substitution elasticities between low-skilled labor and capital, ranging between 1.4 and 1.7, but much smaller ones in the size of 0.5 to 0.7 between high-skilled labor and capital. ${ }^{14}$ To replicate the pattern of the German skill premium of the $9^{\text {th }}$ to $5^{\text {th }}$, the $9^{\text {th }}$ to $1^{\text {st }}$, and the $5^{\text {th }}$ to $1^{\text {st }}$ decile limit of earnings during the period from 1991 to 2005, we apply a value of 0.51 for the substitution elasticity between high-skilled labor and capital. This number is quite close to the estimate by Lindquist, who suggests a substitution elasticity of 0.52 between high-skilled labor and capital for the Swedish economy. ${ }^{15}$

For the substitution elasticity between medium-skilled labor and the capital-skill input and that between low-skilled labor and the intermediate input, we apply values of 1.33 and 2.1, respectively. The last figure, in particular, seems to be substantially larger compared with the substitution elasticities between low-skilled labor and capital of 1.4 or 1.67 found by Lindquist or Krussel et al., respectively. When comparing these numbers one has, however, to consider that neither the study by Lindquist nor by Krussel et al. distinguishes between low- and mediumskilled labor. If we take low- and medium-skilled labor together and compute the weighted average of the joint substitution elasticity between the low- and medium-skilled labor aggregate and capital, we come up with a value of 1.48, which is between the estimate of 1.4 and 1.7 proposed by Lindquist and Krussel et al., respectively. ${ }^{16,17}$

Turning to the behavioral parameters for skill-specific labor supply, we find a multitude of studies dealing with labor supply elasticities of German households, but the empirical evidence on skill-specific labor supply elasticities for German workers is rather scarce. Fehr (1999) provides some simulation results for compensated labor supply elasticities for the lowest, the third, and the top quintile of earnings. These data are, however, not appropriate to replicate the observed pattern in the skill-specific German labor supply during the analyzed period from 1991 to 2005. Therefore, we take Fehr's (1999) estimates just as a starting point and adjust the skill-specific labor supply elasticities in a stepwise process by trial and error in order to exactly replicate the actual pattern in the German skill premia and skill-specific German labor supply. ${ }^{18}$ After this calibration procedure we come up with a labor supply elasticity of 0.89 for low-skilled labor, 0.25 for medium-skilled labor, and 0.8 for high-skilled labor. On average, these figures propose a

\footnotetext{
${ }^{14}$ Since all of the empirical studies that estimate substitution elasticities in the presence of capital-skill complementarity apply just a two-level production technology we miss an empirically founded estimate for the substitution elasticity between medium-skilled labor and capital.

${ }^{15}$ Krussel et al. (2000) suggest a slightly larger substitution elasticity of 0.67 between high-skilled labor and capital using US data.

${ }^{16}$ If we take low- and medium-skilled labor together, low-skilled labor accounts for about 20 percent of this joint labor aggregate. Accordingly the weighted average of the joint substitution elasticity between low- and medium-skilled labor and capital is given by: $0.2 * 2.1+0.8 * 1.33=1.48$.

${ }^{17}$ The empirical evidence for the German economy by FitzRoy and Funke (1995) deviates quite significantly from the above numbers. They find a much lower elasticity of substitution of only 0.50 between low-skilled labor and capital and one of 0.21 between high-skilled labor and capital using data on 32 West German manufacturing industries during the period 1975-1995.

${ }^{18} 18$ For a more detailed discussion on the calibration strategy for substitution and labor supply elasticities see the subsection "Simulation Strategy and Replication Check."
} 
weighted, economy-wide labor supply elasticity of about $0.5 .{ }^{19}$ Surprisingly, this figure is almost identical to the value of 0.51 , which Feldstein (2005) proposes as an applicable estimate for the average compensated labor supply elasticity in macro models.

Finally, the intertemporal elasticity of substitution is set to 0.4 . This value is based on Flaig's (1988) empirical research for Germany, and is slightly lower than the values applied by Keuschnigg and Dietz (2004) in their study for Switzerland or the one by Valkonen (1999).

\section{Macroeconomic Data}

Given the specification of the behavioral parameters as described in the previous section, our dynamic CGE model is able to replicate the most important economic variables of the German economy quite closely. Table 2 reports the main German macroeconomic aggregates for 2005, the 5-year averages, and the aggregates replicated by our CGE model. ${ }^{20}$

GDP and private consumption expenditures are set exogenously in the calibration while all other variables are determined endogenously by our model when computing the steady-state equilibrium. In the phase of transition all variables adjust endogenously after a policy shock. If we compare the 5-year averages of the macro aggregates with those replicated by our model, we come up with a quite good fit. None of the macro aggregates replicated by the model exceeds the 5-year averages by much.

Table 2: Replicated Macroeconomic Structure (in Bn. Euros)

\begin{tabular}{lccc}
\hline \hline & Germany & Medium Run & \multirow{2}{*}{ CGE Model } \\
\cline { 2 - 4 } GDP & 2005 & Average & $2244.6^{*}$ \\
Private Consumption & 2244.6 & 2312.7 & $1326.4^{*}$ \\
Compensation of Employees & 1326.4 & 1330.1 & 1145.9 \\
Capital Stock & 1131.0 & 1146.7 & 6776.1 \\
Depreciation & 6771.4 & 6776.4 & 338.8 \\
Gross Capital Formation & 335.6 & 334.2 & 406.6 \\
\hline
\end{tabular}

Note: Variables marked with a ${ }^{*}$ are set exogenously to replicate the initial steady-state of the German economy.

Source: Destatis (2005), own calculation.

The actual development of the German capital stock, the skill distribution of the German population and the German labor force, as well as the evolution of the German skill premia measured by the $9^{t h}$ to $1^{s t}$, the $9^{t h}$ to $5^{t h}$, and the $5^{\text {th }}$ to $1^{\text {st }}$ decile limit of earnings, respectively, are presented in Table 3.

The data on the German capital stock are taken from a quite recent publication of the German statistical office (Destatis 2006a), which follows the definition of the OECD manual on Measuring Capital. As reported, the overall German capital stock increased from 8.194 bn. Euros in 1991 to 11.162 bn. Euros in 2005, mapping an overall growth performance of 36.2 percent. $^{21}$

\footnotetext{
${ }^{19}$ While low-skilled labor accounts for 14.7 percent of total labor supply in Germany, medium-skilled labor accounts for 57.8 percent and high-skilled labor for the remaining 27.5 percent. Accordingly, the weighted, economy-wide labor supply elasticity is computed by: $0.147 * 0.89+0.578 * 0.25+0.275 * 0.8=0.495$.

${ }^{20}$ The medium-run average is computed over the period from 2003 to 2007.

${ }^{21}$ In terms of capital endowment per worker, the capital intensity increased form 212,000 Euros in 1991 to 288,000 Euros in 2005 , or by 38.8 percent.
} 
When tracing the evolution in the skill distribution of German workers, we rely on data from the German micro census (Destatis 1994, 2006) that contain information on German employees sorted by age and educational attainment. ${ }^{22}$ The group of low-skilled individuals are defined as those with no vocational training while the group of medium-skilled workers are those employees who successfully completed an apprenticeship. To qualify as high-skilled, an individual either completed technical college or holds a university degree.

As reported in Table 3, the number of people in the German labor force (LF) with no vocational training declined slightly by 0.7 percent from 1991 to 2005 . Next, the share of workers who had served an apprenticeship declined by 3.3 percent during the analyzed period while the fraction of people holding a university diploma increased by 8.3 percent. $^{23}$

Table 3: Labor Force, Capital Stock and Skill Premia in Germany

\begin{tabular}{|c|c|c|c|c|c|c|}
\hline \multirow[b]{3}{*}{ Capital Stock } & \multicolumn{2}{|c|}{1991} & \multicolumn{2}{|c|}{2005} & \multicolumn{2}{|c|}{ \%-age Change } \\
\hline & $\operatorname{total}^{3)}$ & $\mathrm{pW}^{4)}$ & total & $\mathrm{pW}$ & $\mathrm{pW}$ & total \\
\hline & 8,194 & 212 & 11,162 & 288 & 38.8 & 36.2 \\
\hline Skill Types (in \%) & $\mathrm{TP}^{1)}$ & $\mathrm{LF}^{2)}$ & $\mathrm{TP}$ & $\mathrm{LF}$ & $\mathrm{TP}$ & $\mathrm{LF}$ \\
\hline Low & 19.8 & 14.8 & 18.4 & 14.7 & -7.1 & -0.7 \\
\hline Medium & 58.4 & 59.8 & 57.0 & 57.8 & -2.4 & -3.3 \\
\hline High & 21.8 & 25.4 & 24.7 & 27.5 & 13.3 & 8.3 \\
\hline Skill Premia & 1991 & $3 Y-A v .{ }^{5)}$ & 2005 & $3 \mathrm{Y}-\mathrm{Av}$ & '91 -' 05 & 3Y-Av. \\
\hline D9/D1 & 2.83 & 2.78 & 3.13 & 3.12 & 10.7 & 12.2 \\
\hline D9/D5 & 1.71 & 1.71 & 1.84 & 1.81 & 7.5 & 5.8 \\
\hline D5/D1 & 1.65 & 1.63 & 1.70 & 1.73 & 2.8 & 6.1 \\
\hline
\end{tabular}

The data on the three different skill premia are taken from the OECD database on Earnings Distribution, ${ }^{24}$ and cover gross monthly earnings of German full-time workers for each decile limit of earnings. The time series on Earnings Distribution provides yearly data from 1984 to 2006 such that it enables us to compute the change in the different skill premia by taking yearly figures for 1991 and 2005 as well as 3-year averages around 1991 and 2005. The latter turns out to be of particular importance since the yearly figures may be substantially distorted due to inflation or price shocks. If we rely solely on the changes between 1991 and 2005 the data indicate an increase of 7.5 percent in the skill premium of the $9^{\text {th }}$ to $5^{\text {th }}$ decile limit of earnings. Taking the 3-year averages, however, the change in the corresponding skill premium amounts to only 5.8 percent. Similarly, taking the yearly figures for 1991 and 2005, the change in the skill premium of the $5^{\text {th }}$ to $1^{\text {st }}$ decile limit of earnings amounts to just 2.8 percent, which is substantially lower than the average earnings dispersion of the $5^{\text {th }}$ to $1^{\text {st }}$ decile limit of earnings which amounted to 6.1 percent. Finally, the change in the skill premium of the $9^{\text {th }}$ to $1^{\text {st }}$ decile

\footnotetext{
${ }^{22}$ To exclude those employees who are still in the process of education, we restrict our calculations to the German population ages 25 to 65 .

${ }^{23}$ In terms of working population, the number of people with no education or a completed apprenticeship declined by 7.1 and 2.4 percent, respectively, while the number of university graduates increased by 13.3 percent during the analyzed period.

${ }^{24}$ The OECD database itself refers to the German Socio-Economic Panel as the underlying data base.
} 
limit of earnings amounted on average to 12.2 percent. Thus, it is slightly higher than the change indicated by the figures for 1991 and 2005 .

\section{Simulation Strategy, Replication Check and Solution Strategy}

After the specification of all functional forms and behavioral parameters, our dynamic CGE model is able to replicate the stationary long-run equilibrium of the 2005 German economy. To quantify the evolution in the respective skill premia and skill distribution over the period from 1991 to 2005 we consider the following strategy: We disturb the initial steady-state equilibrium by reducing the capital stock by exactly that amount by which the capital stock actually increased between 1991 and 2005. By doing so, the model computes the whole phase of transition from the initial to the final steady state and thereby replicates the phase of capital accumulation as well as the resulting time paths for each wage rate, e.g. skill premia, within the analyzed period. ${ }^{25}$

Replication Check: Before we start the simulation analysis it is advisable to check whether the time paths reproduced by our dynamic CGE model are consistent with the actual development of the respective German macro aggregates. If we stick to the estimates for the substitution and labor supply elasticities found in the empirical literature, the simulated time path deviates significantly from the actual pattern in the skill premia and the actual changes in skill-specific labor supply. Therefore, we alter the different elasticities in a stepwise process in order to improve the quality of our model's fit when replicating actual German data.

Table 4: Actual and Replicated Data

\begin{tabular}{lcccc}
\hline \hline Actual Data & Rep. 1 & Rep. 2 & Rep. 3 & Rep. 4 \\
\hline Substitution Elasticities: $\sigma_{L} / \sigma_{M} / \sigma_{H}$ & $1.67 / 1.00 / 0.67$ & $2.32 / 1.00 / 0.60$ & $1.67 / 1.00 / 0.67$ & $2.1 / 1.33 / 0.51$ \\
Supply Elasticities:. $\varepsilon_{L} / \varepsilon_{M} / \varepsilon_{H}$ & $0.49 / 0.54 / 059$ & $0.49 / 0.54 / 059$ & $0.6 / 0.14 / 1.2$ & $0.89 / 0.25 / 0.8$
\end{tabular}

$\Delta$ Skill Premia during the Period $1991-2005$ (in \%)

\begin{tabular}{cccccc}
\hline D9/D1 & $\mathbf{1 2 . 2}$ & 8.24 & 12.2 & 3.11 & $\mathbf{1 2 . 2}$ \\
D9/D5 & $\mathbf{5 . 8}$ & 4.25 & 5.66 & -5.28 & $\mathbf{5 . 7 9}$ \\
D5/D1 & $\mathbf{6 . 1}$ & 3.83 & 6.16 & 8.85 & $\mathbf{6 . 0 7}$ \\
$\Delta$ Skill Distribution during the Period & $1991-2005$ (in \%) & & \\
\hline Low & $\mathbf{- 0 . 7}$ & -2.90 & -4.01 & -0.73 & $\mathbf{- 0 . 7 2}$ \\
Medium & $\mathbf{- 3 . 3}$ & -0.47 & -0.52 & -3.34 & $\mathbf{- 3 . 3 2}$ \\
High & $\mathbf{8 . 3}$ & 2.66 & 3.44 & 8.29 & $\mathbf{8 . 2 4}$ \\
\hline \hline
\end{tabular}

Source: Own calculations.

Table 4 reports the impact of a variation of the substitution elasticities, $\sigma_{i}$, and supply elasticities, $\varepsilon_{i}, i \in\{L, M, H\}$, on the various skill premia and skill distribution. The first column in Table 4 repeats the actual development in the German skill premia and German skill distribution while the second column (Rep. 1) presents our simulation results when we calibrate our model using the empirical data on the substitution and labor supply elasticities provided by Krussel et al. (2000) and Fehr (1999). It becomes obvious that the skill premia as predicted by our model are too small as compared with the actual development in the skill

\footnotetext{
${ }^{25}$ Since the initial and final steady states are predetemined, the intertemporal problem at hand depicts a TwoPoint Boundary Problem that is solved using a Generalized Fair Taylor Algorithm.
} 
premia. In addition, the replicated structure of the skill distribution fails to match the actual development. ${ }^{26}$ Thus, we change the substitution and labor supply elasticities to improve our model's fit. The effects resulting from the change in the respective elasticities are reported in columns Rep. 2 and Rep. 3 of Table 4.

To push the computed results in the direction of the actual pattern of the skill premium, we increase the substitution elasticity between low-skilled labor and the capital-skill input, $\sigma_{L}$, but reduce the one between capital and high-skilled labor, $\sigma_{H}$. Therewith, the complementarity within the capital-skill input becomes even stronger, leading to an increase in high-skilled wages, while low-skilled labor becomes even more easily substitutable, resulting in a decline of lowskilled wages. As a consequence, the skill premia of the $9^{\text {th }}$ to $1^{\text {st }}$ and the $5^{\text {th }}$ to $1^{\text {st }}$ decile limit of earnings increase.

In addition, an alteration in the labor supply elasticities is necessary to map the actual evolution in the German skill distribution. If we calibrate the degree of capital-skill complementarity according to that estimated by Krussel et al. (2000), we require labor supply elasticities of the values $0.6,0.14$, and 1.2 for low-, medium-, and high-skilled labor, respectively. A variation in the labor supply elasticities, however, affects not only the supply of the different labor skill type and thereby the skill distribution of the labor force, but it additionally influences the respective wage rates and thereby the resulting skill premia. Hence, we search for a constellation of substitution and labor supply elasticities by trial and error, which enables us to simultaneously replicate the true pattern of the German skill premia and skill distribution of the labor force in Germany.

One parameter constellation (column Rep. 4 in Table 4) that fits the actual figures quite well implies substitution elasticities of $\sigma_{L}=2.1, \sigma_{M}=1.33, \sigma_{H}=0.51$, and labor supply elasticities in the range of $\varepsilon_{L}=0.89, \varepsilon_{M}=0.25, \varepsilon_{H}=0.8$. As mentioned above, the values for the substitution elasticities are largely in line with the estimates by Krussel et al. (2000) or Lindquist (2005), if we regard low- and medium-skilled labor as one joint skill type as done in their work. The labor supply elasticities also add up to an aggregate, economy-wide labor supply elasticity of about 0.5 , which is consistent with the value of 0.51 suggested by Feldstein (2005) as an applicable value for macro models. This constellation of substitution and supply elasticities serves as a benchmark for all future simulations conducted in the subsequent chapter.

Solution Strategy: The nature of the firm's and the household's intertemporal problem is characterized by a two-point boundary problem since the initial and final steady-state equilibria are known. ${ }^{27}$ The phase of transition between these two equilibria is represented by a sequence of temporary equilibria that are connected by a number of predetermined and forward-looking variables. Since perfect foresight is assumed, the forward-looking variables represent a set of expectations that reflect the information inherent in the future equilibrium, i.e., firm values represent the present value of future dividend payments while human capital reflects the present value of future wages. ${ }^{28}$

For the solution to the two-point boundary problem we apply an iterative technique. Start-

\footnotetext{
${ }^{26}$ In particular, the model predicts the largest reduction for low-skilled labor supply, while in reality the supply of medium-skilled labor was hit by the sharpest decline.

${ }^{27}$ Both, the initial and final steady-state equilibria are characterized by a specific constellation of the behavioral parameters determining technology and preferences according to the counterfactual analysis conducted.

${ }^{28} \mathrm{An}$ additional issue relates to the uniqueness and stability of the computed equilibrium. Since the model's core consists of a neoclassical investment problem imbedded in a standard growth model that features a unique and stable equilibrium, our model also ensures uniqueness and stability.
} 
ing with a first guess for the set of expectations that satisfy the final steady state, a sequence of temporary equilibria is computed by solving the system of the model's nonlinear differential equations. During this first step of iteration, the computed vector of expected variables still varies from the actual values prevailing in the temporary equilibria. Therefore, the set of expectations is updated according to the results obtained by the sequence of temporary equilibria. The second iteration applies this updated set of expectations in order to compute a new sequence of temporary equilibria, which again yields a set of revised expectations. The alignment and updating of the set of expectations is carried out by a generalized Fair-Taylor algorithm that will stop the iteration process if the discrepancy between the expected and actual variables resulting from the sequence of temporary equilibria has become sufficiently small, i.e., $e^{-14}$.

\section{Simulation Results}

\subsection{The Complementarity Effect}

Following the empirical implementation of our model outlined in the previous section, highskilled labor is the only production factor that constitutes a complement to capital while both medium- and low-skilled labor are substitutes to capital. As a consequence of this structural formulation, the accumulation of capital increases first and foremost the demand for high-skilled labor and thereby the wage rate of the high-skilled. This explains the positive impact of capital accumulation on the skill premium of the high-skilled in the presence of capital-skill complementarity. In quantitative terms, the German skill premium of the $9^{\text {th }}$ to $1^{\text {st }}$ decile limit of earnings rose by 12.2 percent during the last 15 years (from 1991 to 2005), while the ones defined by the $9^{\text {th }}$ to $5^{\text {th }}$ and the $5^{\text {th }}$ to $1^{\text {st }}$ decile limit of earnings rose by just 5.8 and 6.1 percent, respectively.

The first class of simulations is devoted to the Complementarity or Demand Side Effect. This implies that we quantify the impact resulting from a variation of the substitution elasticities on the different skill premia and on skill-specific labor demand.

Table 5: The Complementarity Effect

\begin{tabular}{|c|c|c|c|c|}
\hline & Actual Data & Scenario 5.1 & Scenario 5.2 & Scenario 5.3 \\
\hline$\sigma_{L} / \sigma_{M} / \sigma_{H}$ & $2.1 / 1.33 / 0.51$ & $1.0 / 1.0 / 1.0$ & $2.1 / 1.33 / 0.51$ & $1.0 / 1.0 / 1.0$ \\
\hline$\varepsilon_{L} / \varepsilon_{M} / \varepsilon_{H}$ & $0.89 / 0.25 / 0.8$ & $0.89 / 0.25 / 0.8$ & $0.51 / 0.51 / 0.51$ & $0.51 / 0.51 / 0.51$ \\
\hline \multicolumn{5}{|c|}{$\Delta$ Skill Premia (in \%) } \\
\hline D9/D1 & 12.2 & 0.48 & 16.5 & -0.001 \\
\hline D9/D5 & 5.79 & -4.33 & 12.8 & -0.001 \\
\hline D5/D1 & 6.07 & 5.02 & 3.28 & $3.6 e^{-13}$ \\
\hline \multicolumn{5}{|c|}{$\Delta$ Skill Distribution (in \%) } \\
\hline Low & -0.7 & 3.04 & -3.0 & $-/-$ \\
\hline Medium & -3.3 & -1.90 & -1.39 & $-1-$ \\
\hline High & 8.3 & 2.55 & 4.84 & $-1-$ \\
\hline
\end{tabular}

Source: Own calculations.

Starting from the model's baseline calibration, which allows us to replicate the actual changes in the German skill premia and the skill distribution of the German labor force, we perform a counterfactual analysis and compute the counterfactual changes in the skill premia and the 
skill distribution resulting in a world with no capital-skill complementarity. In doing so, we set all substitution elasticities equal to one (see Scenario 5.1), such that the variation in the skill premia and skill distribution is solely driven by the actual skill-specific labor supply elasticities prevailing in Germany. Interestingly, under uniform substitution elasticities, the accumulation of capital during the 15-year period from 1991 to 2005 has almost no impact on the skill premium of the $9^{\text {th }}$ to $1^{\text {st }}$ decile limit of earnings. The latter increases by just 0.5 percent over the period of 1991 to 2005. However, the actual pattern in German labor supply elasticities generates a significant negative impact on the skill premium of the $9^{\text {th }}$ to $5^{\text {th }}$ decile limit of earnings, which in the absence of capital-skill complementarity declines by about 4.3 percent during the analyzed period. By contrast, the skill premium of the $5^{\text {th }}$ to $1^{\text {st }}$ decile limit of earnings rises by more than 5.0 percent.

If we compare the actual changes in the skill premia with those computed under the counterfactual analysis (Scenario 5.1) we find that the feature of capital-skill complementarity has a particularly enhancing impact on German skill premia. In the presence of capital-skill complementarity the increase in the skill premia defined by the $9^{\text {th }}$ to $1^{\text {st }}$ and the $9^{\text {th }}$ to $5^{\text {th }}$ decile limit of earnings turns out to be by about 11.7 and 10.1 percentage points larger (over the 15-year period from 1991 to 2005) as compared with a world with no capital-skill complementarity.

To isolate the complementarity (demand side) effect from the quantity (supply side) effect, that is, to eliminate the influence of the differentiated labor supply elasticities on the skill premia, we apply identical supply elasticities of 0.51 for each labor skill type ${ }^{29}$ in Scenarios 5.2 and 5.3. Given identical supply elasticities for each labor skill type, we once again quantify the variation in the skill premia resulting under the presence and absence of capital-skill complementarity.

In the presence of capital-skill complementarity but uniform labor supply elasticities (see Scenario 5.2), we find an even stronger spread between high-skilled and low- and medium-skilled wages but a much smaller one between medium- and low-skilled wages as compared with the actual German situation. Specifically, the skill premia of the $9^{\text {th }}$ to $1^{\text {st }}$ and the $9^{\text {th }}$ to $5^{\text {th }}$ decile limit of earnings increase by 16.5 and 12.8 percent, respectively, over the 15-year period from 1991 to 2005 , while that of the $5^{\text {th }}$ to $1^{\text {st }}$ decile limit of earnings rises by just 3.3 percent.

In the absence of capital-skill complementarity and identical labor supply elasticities (see Scenario 5.3), the accumulation of capital has an impact neither on the development of the skill premia nor on the skill distribution. The zero variation in the skill premia and skill distribution is explained by the uniform rise in skill-specific wages ${ }^{30}$ and the uniform demand shift in favor of each skill type. Comparing the results found under Scenarios 5.2 and 5.3, we find an even stronger impact of capital-skill complementarity on the skill premia when we disregard the quantity (supply side) effect.

To summarize, under uniform labor supply elasticities the feature of capital-skill complementarity boosts the skill premia of the $9^{\text {th }}$ to $1^{\text {st }}$ and the $9^{\text {th }}$ to $5^{\text {th }}$ decile limit of earnings by about 16.5 and 12.8 percent, respectively, over the analyzed 15-year period from 1991 to 2005, while the skill premia stay unchanged in a world of uniform labor supply elasticities and no capital-skill complementarity. Accordingly, these figures imply a yearly increase of 1.03 and 0.8 percent in the respective skill premia of the $9^{\text {th }}$ to $1^{\text {st }}$ and the $9^{\text {th }}$ to $5^{\text {th }}$ decile limit of earnings

\footnotetext{
${ }^{29} \mathrm{~A}$ uniform labor supply elasticity of 0.51 seems to be appropriate for two reasons. First, the weighted average of the applied skill-specific labor supply elasticities amounts to about 0.5. Second, Feldstein (2005) proposes a value of 0.51 as an applicable estimate for the average compensated labor supply elasticity in macro models.

${ }^{30}$ In the absence of capital-skill complementarity and uniform labor supply elasticities of 0.51 , the model computes a uniform increase in skill-specific wages of 12.8 percent over the 15-year period from 1991 to 2005.
} 
due to capital-skill complementarity. Since the applied substitution elasticities are broadly in line with the findings for the United States and Sweden (see, for example, Krussel et al. 2000, or Lindquist 2005), we claim that our estimates are also a rough approximation for the impact of capital-skill complementarity on the skill premia in these countries.

In the next set of simulations we analyze how the skill premia and the skill distribution change under an even stronger (or weaker) degree of capital-skill complementarity. In doing so, we define a 1, 5, and 10 percent stronger (weaker) degree of capital-skill complementarity by a 1 , 5 , and 10 percent increase (decrease) in the substitution elasticities of those production factors that are substitutes and an equally large decrease (increase) in the substitution elasticities of those factors that are complements. ${ }^{31}$ Table 6 reports the findings of our second counterfactual analysis. The numbers in brackets resemble percentage changes computed relative to the actual variation in the German skill premia.

Table 6: The Complementarity Effect Reconsidered

\begin{tabular}{|c|c|c|c|c|c|c|c|}
\hline & $+10 \%$ & $\begin{array}{l}+5 \% \\
\text { onger C }\end{array}$ & $+1 \%$ & $\begin{array}{c}\text { actual } \\
\text { data }\end{array}$ & $-1 \%$ & $\begin{array}{c}-5 \% \\
\text { weaker CSC }\end{array}$ & $-10 \%$ \\
\hline \multicolumn{8}{|c|}{$\Delta$ Skill Premia (in \%) } \\
\hline D9/D1 & 14.1 & 13.2 & 12.4 & 12.2 & 12.0 & 11.3 & 10.3 \\
\hline$(\Delta$ in $\%)$ & $(+15.6)$ & $(+8.0)$ & $(+1.7)$ & & $(-1.4)$ & $(-7.6)$ & $(-15.4)$ \\
\hline D9/D5 & 8.14 & 6.97 & 6.03 & 5.79 & 5.56 & 4.60 & 3.38 \\
\hline$(\Delta$ in $\%)$ & $(+40.6)$ & $(+20.4)$ & $(+4.2)$ & & $(-4.0)$ & $(-20.6)$ & $(-41.7)$ \\
\hline D5/D1 & 5.55 & 5.79 & 6.01 & 6.07 & 6.13 & 6.38 & 6.72 \\
\hline$(\Delta$ in $\%)$ & $(-8.6)$ & $(-4.5)$ & $(-0.9)$ & & $(+1.0)$ & $(+5.0)$ & $(+10.7)$ \\
\hline \multicolumn{8}{|c|}{$\Delta$ Skill Distribution (in \%) } \\
\hline Low & -1.14 & -0.93 & -0.76 & -0.72 & -0.67 & -0.50 & -0.28 \\
\hline$(\Delta$ in $\%)$ & $(-58.1)$ & $(-29.1)$ & $(-5.54)$ & & $(+6.35)$ & $(+30.4)$ & $(+61.2)$ \\
\hline Med. & -3.62 & -3.47 & -3.35 & -3.32 & -3.30 & -3.18 & -3.03 \\
\hline$(\Delta$ in $\%)$ & $(-8.96)$ & $(-4.54)$ & $(-1.02)$ & & $(+0.74)$ & $(+4.26)$ & $(+8.70)$ \\
\hline High & 9.29 & 8.77 & 8.35 & 8.24 & 8.14 & 7.72 & 7.20 \\
\hline$(\Delta$ in $\%)$ & $(+12.8)$ & $(+6.37)$ & $(+1.29)$ & & $(-1.24)$ & $(-6.28)$ & $(-12.6)$ \\
\hline
\end{tabular}

Source: Own calculations.

From a qualitative point of view all variations in the skill premia are in line with economic theory: The particular case of a stronger (weaker) degree of capital-skill complementarity implies that high-skilled labor becomes an even stronger (weaker) complement to capital, and thus any accumulation of capital increases (decreases) the demand and therewith the wage rate of the high-skilled. In addition, the degree of substitutability of low- and medium-skilled labor increases (decreases) under an even stronger (weaker) degree of capital-skill complementarity, explaining the observed rise (drop) in the skill premia defined by the $9^{\text {th }}$ to $1^{\text {st }}$ and the $9^{\text {th }}$ to $5^{\text {th }}$ decile limit of earnings.

In quantitative terms, a 1 percent stronger degree of capital-skill complementarity increases the skill premia of the $9^{\text {th }}$ to $1^{\text {st }}$ and the $9^{\text {th }}$ to $5^{\text {th }}$ decline limit of earnings by 1.7 and 4.2

\footnotetext{
${ }^{31}$ For instance, if we analyze the impact of a 5-percent stronger capital-skill complementarity, we increase the respective substitution elasticity for low- and medium-skilled labor by 5 percent each, while we reduce that for high-skilled labor also by 5 percent. In analyzing a weaker degree of capital-skill complementarity, the modification in substitution elasticities is reverse.
} 
percent, respectively, while that of the $5^{\text {th }}$ to $1^{\text {st }}$ decile limit of earnings declines by almost 1 percent. Remember, all changes once again refer to the 15-year period from 1991 to 2005.

The different magnitudes in the variation of the skill premia resulting from a 1 percent stronger degree of capital-skill complementarity are explained by the changes in skill-specific labor demands as well as the differentiated skill-specific labor supply elasticities. First of all, the increased spread in substitution elasticities leads to reduced demand for low- and mediumskilled labor since both factors constitute substitutes with regard to the capital-skill input. ${ }^{32}$ The declining demand for low- and medium-skilled labor exerts a downward pressure on the respective wage rates, which are particularly large for medium-skilled labor. The latter is the case because medium-skilled labor faces a relatively inelastic supply - compared with low-skilled labor - explaining the slight decline observed in the skill premium of the $5^{\text {th }}$ to $1^{\text {st }}$ decile limit of earnings. Moreover, the increased demand for high-skilled labor raises the wage of the highskilled and hence explains the observed increase in the skill premia of the $9^{\text {th }}$ to $1^{\text {st }}$ and the $9^{\text {th }}$ to $5^{\text {th }}$ decile limit of earnings.

For even stronger degrees of capital-skill complementarity, the variation in the skill premia turns out to be almost proportional to the variation resulting from the 1-percent increase. The same is also true of weaker degrees of capital-skill complementarity, i.e., the magnitude of the changes in the skill premia under a weaker degree of capital-skill complementarity are almost identical to the ones occurring under a stronger degree of the capital-skill complementarity, but algebraic signs are of reverse order.

Our interim result regarding the complementarity effect states as follows: The complementarity or demand side effect has a substantial influence on the emerging skill premia. In case of factor substitution elasticities in line with the ones found in the empirical literature and uniform skill-specific labor supply elasticities, the feature of capital-skill complementarity raises the skill premia of the $9^{\text {th }}$ to $1^{\text {st }}$ and the $9^{\text {th }}$ to $5^{\text {th }}$ decile limit of earnings by more than 1.0 and 0.8 percent, respectively, on a yearly basis. That of the $5^{\text {th }}$ to $1^{\text {st }}$ decile limit of earnings rises by more than 0.2 percent per year. In addition, we show that in Germany an increased spread in substitution elasticities boosts in particular the skill premium of the $9^{\text {th }}$ to $5^{\text {th }}$ decile limit of earnings while the impact on the skill premium of the $9^{\text {th }}$ to $1^{\text {st }}$ decile limit of earnings is relatively moderate. This difference is explained by the skill-specific labor supply elasticities, i.e., the inelastic supply of medium-skilled labor.

\subsection{Sensitivity Analysis: Complementarity Effect}

In the following sensitivity analysis we analyze the impact of a variation in each substitution elasticity separately to get a more detailed insight into the quantitative importance of the complementarity effect. In doing so, we start from our benchmark simulation (normal labor supply elasticities) and increase each of the three substitution elasticities, $\sigma_{i}, i \in\{L, M, H\}$, by 1

\footnotetext{
${ }^{32} \mathrm{~A}$ 1-percent increase in the degree of capital skill complementarity reduces the demand for low-skilled labor by more than 5.5 percent while the demand for medium-skilled labor decreases by only 1 percent over the 15-year period from 1991 to 2005 . The answer to this finding refers on the one hand to the quite large substitution elasticity between low-skilled labor and the intermediate input, but, on the other hand, low-skilled labor amounts to less than 15 percent of the total working force such that a moderate absolute decline in the demand for lowskilled workers results in a major relative change in low-skilled labor demand compared with a moderate absolute decline in medium- or high-skilled labor. The latter two skill types amount to about 58 and 27 percent of the total labor force, respectively. The variation in the skill distribution resulting under an even stronger or weaker degree of capital-skill complementarity also turns out to be almost proportional to the 1-percent variation.
} 
percent. ${ }^{33}$ Our results are summarized in Table 7.

As a consequence of the 1-percent increase in the substitution elasticity for low-skilled labor from 2.1 to 2.12 percent, low-skilled labor becomes less important in production, resulting in a decline in the respective wage rate. In turn, the skill premia of the $9^{\text {th }}$ to $1^{\text {st }}$ and the $5^{\text {th }}$ to $1^{\text {st }}$ decile limit of earnings increase. However, the 1-percent increase in the substitution elasticity of low-skilled labor increases the two before-mentioned skill premia by less than 1 percent, while the demand for low-skilled labor declines by about 4.8 percent. All results refer to the 15-year period from 1991 to 2005.

Table 7: Sensitivity Analysis: Substitution Elasticities

\begin{tabular}{|c|c|c|c|c|}
\hline & & $\begin{array}{c}\sigma_{L}: 2.1 \\
\rightarrow 2.121\end{array}$ & $\begin{array}{l}\sigma_{M}: 1.33 \\
\rightarrow 1.343\end{array}$ & $\begin{array}{c}\sigma_{H}: 0.51 \\
\rightarrow 0.515\end{array}$ \\
\hline$\Delta \mathrm{D} 9 / \mathrm{D} 1$ & \multirow{2}{*}{12.2} & 12.3 & 12.2 & 12.10 \\
\hline$(\Delta$ in $\%)$ & & $(+0.43)$ & $(+0.18)$ & $(-0.92)$ \\
\hline$\Delta \mathrm{D} 9 / \mathrm{D} 5$ & \multirow[t]{2}{*}{5.79} & 5.79 & 5.93 & 5.70 \\
\hline$(\Delta$ in $\%)$ & & $(-0.01)$ & $(+2.34)$ & $(-1.67)$ \\
\hline$\Delta \mathrm{D} 5 / \mathrm{D} 1$ & \multirow[t]{5}{*}{6.09} & 6.12 & 5.96 & 6.06 \\
\hline$(\Delta$ in $\%)$ & & $(+0.82)$ & $(-1.88)$ & $(-0.11)$ \\
\hline$\Delta L_{L}($ in $\%)$ & & -4.84 & +1.51 & +2.50 \\
\hline$\Delta L_{M}($ in $\%)$ & & +0.17 & -0.42 & +0.61 \\
\hline$\Delta L_{H}($ in $\%)$ & & +0.08 & +0.36 & -0.78 \\
\hline Applied Labo & sticiti & $L_{L}=0.89$ & $=0.25 ; \varepsilon_{H}$ & $.8)$ \\
\hline
\end{tabular}

A 1-percent increase in the substitution elasticity for medium-skilled labor has a major impact on the skill premia of the $9^{t h}$ to $5^{t h}$ and the $5^{t h}$ to $1^{s t}$ decile limit of earnings. The former increases by 2.3 percent while the latter drops by almost 2 percent. These changes are in line with the economic intuition resulting from a decline in the wage rate for medium-skilled labor. The computed demand changes show that firms require less medium-skilled labor $(-0.42$ percent) and employ more low-skilled labor $(+1.5$ percent $)$ and a little more high-skilled labor $(+0.36$ percent $)$ instead. ${ }^{34}$

Lastly, a 1-percent change in the elasticity governing the substitutability of high-skilled labor indicates a decline in each of the three skill premia. However, the decline in the skill premium of the $9^{\text {th }}$ to $5^{\text {th }}$ decile limit of earnings over the 15 -year period is the most pronounced $(-1.7$ percent) followed by that of the $9^{\text {th }}$ to $1^{\text {st }}$ decile limit of earnings (-0.9 percent).

\subsection{The Relative Quantity Effect}

The second class of simulations focuses on the Quantity Effect or Supply Side Effect. This effect specifies the impact of an alteration in skill-specific labor supply on the skill premia and skill distribution. From a theoretical point of view, the direction of the quantity effect, i.e. an increase in skill-specific labor supply, is straightforward: On a ceteris paribus basis, an isolated

\footnotetext{
${ }^{33}$ The sensitivity analysis in the form of a 1 -percent variation in each substitution elasticity under inelastic labor supply can be found in the Appendix.

${ }^{34}$ Since medium-skilled labor constitutes the largest fraction of labor in quantitative terms, the decline in medium-skilled labor supply resulting from a 1-percent increase in the substitution elasticity of medium-skilled labor appears to be relatively small.
} 
increase in the supply of high-skilled labor, for instance, causes a decline in high-skilled wages and therewith results in an alleviating impact on the skill premia defined by the $9^{t h}$ to $1^{s t}$ and the $9^{\text {th }}$ to $5^{\text {th }}$ decile limit of earnings. Following the same line of arguments, a reduction in the supply of low- and medium-skilled labor raises the respective wage rates and has therewith also an alleviating impact on the above-mentioned skill premia. The actual variation in the German skill distribution over the analyzed period from 1991 to 2005 was marked by a similar pattern: The supply of low- and medium-skilled labor declined by 0.72 and 0.33 percent, respectively, while the supply of high-skilled labor increased by more than 8.2 percent. Accordingly, from a theoretical point of view the constellation of skill-specific labor supply must have had a clearly negative impact on the German skill premia.

To isolate the quantity effect, we once again apply identical labor supply elasticities of 0.51 for each skill type (Scenario 8.1). If we compare the actual variation in the skill premia with the one emerging under identical labor supply elasticities, we find that the skill premia defined by the $9^{\text {th }}$ to $1^{\text {st }}$ and the $9^{\text {th }}$ to $5^{\text {th }}$ decile limit of earnings are significantly larger, while the one defined by the $5^{\text {th }}$ to $1^{\text {st }}$ decile limit of earnings is much lower, compared with the changes observed in the actual data. Accordingly, over the analyzed period from 1991 to 2005 the prevailing pattern of skill-specific labor supply elasticities caused a reduction in the skill premia of the $9^{\text {th }}$ to $1^{\text {st }}$ and the $9^{\text {th }}$ to $5^{\text {th }}$ decile limit of earnings by 4.3 and 7.0 percentage points, respectively. The impact on the skill premium of the $5^{t h}$ to $1^{\text {st }}$ decile limit of earnings amounted to an increase by 2.8 percentage points.

Table 8: The Quantity Effect

\begin{tabular}{cccccc}
\hline \hline & Actual Data & Scenario 8.1 & Scenario 8.2 & Scenario 8.3 & Scenario 8.4 \\
\hline$\sigma_{L} / \sigma_{M} / \sigma_{H}$ & $2.1 / 1.33 / 0.51$ & $2.1 / 1.33 / 0.51$ & $2.1 / 1.33 / 0.51$ & $1.0 / 1.0 / 1.0$ & $1.0 / 1.0 / 1.0$ \\
$\varepsilon_{L} / \varepsilon_{M} / \varepsilon_{H}$ & $0.89 / 0.25 / 0.8$ & $0.51 / 0.51 / 0.51$ & $0.01 / 0.01 / 0.01$ & $0.28 / 0.671 / 0.09$ & $0.41 / 0.18 / 2.86$ \\
$\Delta$ Skill Premia (in \%) & & & & \\
D9/D1 & 12.2 & 16.5 & 36.2 & 12.22 & -8.27 \\
D9/D5 & 5.8 & 12.8 & 30.2 & 5.80 & -10.67 \\
D5/D1 & 6.1 & 3.28 & 4.56 & 6.06 & 2.69 \\
$\Delta$ Skill Distribution (in \%) & & & & -0.72 \\
Low & -0.7 & -3.0 & -0.11 & 6.87 & -3.32 \\
Medium & -3.3 & -1.39 & -0.07 & 0.76 & 8.24 \\
High & 8.3 & 4.84 & 0.20 & -4.78 &
\end{tabular}

Source: Own calculations.

On a yearly basis, the alleviating impact resulting from the differentiated skill-specific labor supply elasticities amounts to -0.28 and -0.45 percent for the skill premia of the $9^{\text {th }}$ to $1^{\text {st }}$ and the $9^{\text {th }}$ to $5^{\text {th }}$ decile limit of earnings, respectively, and to 0.18 percent for the skill premium defined by the $5^{\text {th }}$ to $1^{\text {st }}$ decile limit of earnings. Stated differently, the constellation of skill-specific labor supply elasticities prevailing in Germany induces a yearly decline in the skill premia of the $9^{\text {th }}$ to $1^{\text {st }}$ and the $9^{\text {th }}$ to $5^{\text {th }}$ decile limit of earnings by almost 0.3 and 0.45 percent, respectively. The skill premium defined by the $5^{\text {th }}$ to $1^{\text {st }}$ decile limit of earnings increases by 0.18 percent per year due to the specific constellation of supply elasticities.

Under Scenario 8.2 we analyze the change in skill premia resulting under capital-skill complementarity but inelastic labor supply. Under this scenario, the constellation of factor substitution 
elasticities implies that the increase in the skill premia of the $9^{\text {th }}$ to $1^{\text {st }}$ and the $9^{\text {th }}$ to $5^{\text {th }}$ decile limit of earnings over the period from 1991 to 2005 is almost three and five times larger, respectively, compared with the actual changes in skill premia.

If we take Scenario 8.1 with uniform labor supply elasticities as a benchmark, the impact of switching from elastic to inelastic labor supply is less dramatic. Comparing Scenarios 8.1 and 8.2, the resulting skill premia of the $9^{t h}$ to $1^{\text {st }}$ and the $9^{t h}$ to $5^{t h}$ decile limit of earnings is by "just" 2.2 and 2.4 times larger, respectively, under inelastic labor supply compared with elastic labor supply. ${ }^{35}$

In Scenarios 8.3 and 8.4 we once again perform a counterfactual analysis and search of the "right" skill-specific labor supply elasticities that generate the actual pattern observed in the German skill premia (Scenario 8.3) and the German skill distribution (Scenario 8.4) in the absence of capital-skill complementarity. To replicate the actual pattern in German skill premia in the absence of capital-skill complementarity, a reverse pattern in skill-specific labor supply elasticities is required. Specifically, the supply of low- and high-skilled labor needs to be quite inelastic (supply elasticities of 0.28 and 0.09 , respectively) while medium-skilled labor has to feature the largest supply elasticity of 0.67 .

The next set of simulations is dedicated to the impact of even stronger (or weaker) skillspecific labor supply elasticities. We raise (reduce) each of the labor supply elasticities by 1,5 , and 10 percent, and quantify the impact on the skill premia and the skill distribution. Table 9 reports our findings.

Table 9: The Quantity Effect Reconsidered

\begin{tabular}{|c|c|c|c|c|c|c|c|}
\hline & $\begin{array}{r}+10 \% \\
\text { stron }\end{array}$ & $\begin{array}{l}+5 \% \\
\text { r Labor }\end{array}$ & $\begin{array}{l}+1 \% \\
\text { pply }\end{array}$ & $\begin{array}{c}\text { actual } \\
\text { data }\end{array}$ & $\begin{array}{r}-1 \% \\
\text { wec }\end{array}$ & $\begin{array}{l}-5 \% \\
\text { Labor }\end{array}$ & $\begin{array}{l}-10 \% \\
\text { ply }\end{array}$ \\
\hline \multicolumn{8}{|c|}{$\Delta$ Skill Premia (in \%) } \\
\hline D9/D1 & 11.3 & 11.8 & 12.1 & 12.2 & 12.3 & 12.7 & 13.2 \\
\hline$(\Delta$ in $\%)$ & $(-7.02)$ & $(-3.54)$ & $(-0.62)$ & & $(+0.90)$ & $(+4.08)$ & $(+8.28)$ \\
\hline D9/D5 & 4.91 & 5.34 & 5.70 & 5.79 & 5.89 & 6.29 & 6.80 \\
\hline$(\Delta$ in $\%)$ & $(-15.2)$ & $(-7.74)$ & $(-1.48)$ & & $(+1.65)$ & $(+8.56)$ & $(+17.5)$ \\
\hline D5/D1 & 6.13 & 6.10 & 6.07 & 6.07 & 6.07 & 6.03 & 6.00 \\
\hline$(\Delta$ in $\%)$ & $(+1.02)$ & $(+0.49)$ & $(+0.06)$ & & $(-0.05)$ & $(-0.60)$ & $(-1.17)$ \\
\hline \multicolumn{8}{|c|}{$\Delta$ Skill Distribution (in \%) } \\
\hline Low & -0.66 & -0.69 & -0.71 & -0.72 & -0.72 & -0.74 & -0.77 \\
\hline$(\Delta$ in $\%)$ & $(+7.78)$ & $(+3.89)$ & $(+0.76)$ & & $(-0.05)$ & $(-3.21)$ & $(-6.34)$ \\
\hline Med. & -3.44 & -3.38 & -3.33 & -3.32 & -3.31 & -3.26 & -3.19 \\
\hline$(\Delta$ in $\%)$ & $(-3.51)$ & $(-1.84)$ & $(-0.44)$ & & $(+0.17)$ & $(+1.80)$ & $(+3.78)$ \\
\hline High & 8.50 & 8.37 & 8.27 & 8.24 & 8.22 & 8.09 & 7.93 \\
\hline$(\Delta$ in $\%)$ & $(+3.20)$ & $(+1.64)$ & $(+0.32)$ & & $(-0.29)$ & $(-1.83)$ & $(-3.75)$ \\
\hline
\end{tabular}

Source: Own calculations.

An equal relative increase in skill-specific labor supply elasticities reduces the skill premia of the $9^{\text {th }}$ to $1^{\text {st }}$ and the $9^{\text {th }}$ to $5^{\text {th }}$ decile limit of earnings but has a very small positive impact on

\footnotetext{
${ }^{35}$ Furthermore, we infer from Table 8 that the change in the skill distribution of the population is obviously more pronounced the larger the applied labor supply elasticities are. In case we assume a common labor supply elasticity of 0.51 , the share of high-skilled workers increases by almost 5 percent, while the share of medium- and low-skilled workers declines by 1.4 and 3 percent, respectively.
} 
the skill premium of the $5^{\text {th }}$ to $1^{\text {st }}$ decile limit of earnings. The algebraic signs of the variations are explained as follows: First of all, an increase in the labor supply elasticities leads to a major or minor reduction in skill-specific wages, depending on the initially prevailing supply elasticities. Reliant on the new wage structure, firms reshuffle the labor skill types employed. To state it more precisely, medium-skilled labor faces the lowest supply elasticity and therefore the 1-percent increase in the corresponding supply elasticity leads to an only minor quantity reaction in the supply of medium-skilled labor. Accordingly, the downward pressure exerted on medium-skilled wages remains relatively small. Contrary to that, low- and high-skilled labor are both marked by relatively high supply elasticities, such that both skill types face a major drop in their wage rates due to the 1-percent increase in the supply elasticities. As a consequence, firms substitute medium-skilled labor ( -0.44 per cent) with low- and high-skilled labor $(+0.76$ and +0.32 percent, respectively). Moreover, in equilibrium the relatively stronger demand for low-skilled labor countervails the decline in low-skilled wages. These patterns explain the slight reduction in the skill premium of the $9^{t h}$ to $1^{\text {st }}$ decile limit of earnings, the relatively large drop observed for the skill premium of the $9^{\text {th }}$ to $5^{\text {th }}$ decile limit of earnings, and the tiny increase in the skill premium of the $5^{\text {th }}$ to $1^{\text {st }}$ decile limit of earnings.

Next, if we compare the impact of a 1-percent variation in the substitution elasticities (see Table 6) or labor supply elasticities (see Table 9) on the skill premia, we find a much larger impulse resulting from the variation in substitution elasticities compared with an equally large variation in supply elasticities. On average the complementarity effect has about a 2.5 times larger impact on the skill premia compared with the impact of the quantity effect.

As discussed at the beginning of this section, it is not only the spread within the skill-specific labor supply elasticities that matters; the absolute size of the applied labor supply elasticities also plays a crucial role in the evolution of the skill premia. In general, the larger the applied (uniform) labor supply elasticities, the less pronounced the yearly increase in the skill premia due to the complementarity effect. This finding becomes obvious by the figures presented in Table 10.

Table 10: Yearly Impact of CSC under different Labor Supply Elasticities

\begin{tabular}{|c|c|c|c|c|c|c|c|c|c|c|c|c|c|}
\hline $\begin{array}{r}\varepsilon_{i}= \\
\Delta \text { Skill Pr }\end{array}$ & $\begin{array}{l}0.01 \\
\text { mia }\end{array}$ & $\begin{array}{r}0.26 \\
n \%)\end{array}$ & 0.51 & 0.76 & 1.01 & 1.26 & 1.51 & 1.76 & 2.01 & 2.26 & 2.51 & 2.76 & 3.01 \\
\hline$\Delta \mathrm{D} 9 / \mathrm{D} 1$ & 2.08 & 1.40 & 1.02 & 79 & .63 & .5 & .4 & 0.36 & 0.3 & 0.27 & 0.24 & .21 & 0.19 \\
\hline 5 & 1.78 & 1.14 & 0.80 & 0.60 & 0.47 & 0.38 & 0.31 & 0.26 & 0.22 & 0.19 & 0.17 & 0.15 & 0.13 \\
\hline$\Delta \mathrm{D} 5 / \mathrm{D} 1$ & 0.30 & 0.25 & 0.2 & 0.18 & 0.16 & 0.14 & 0.12 & 0.10 & 0.09 & 0.08 & 0.07 & 0.07 & 0.06 \\
\hline
\end{tabular}

Source: Own calculations.

In the case of almost inelastic labor supply elasticities, the applied constellation of factor substitution elasticities ${ }^{36}$ leads to a yearly increase in the skill premia defined by the $9^{\text {th }}$ to $1^{\text {st }}$ and the $9^{\text {th }}$ to $5^{\text {th }}$ decile limit of earnings of 2.1 and 1.8 percent, respectively. However, a steady increase in labor supply elasticities reduces the positive impact of capital-skill complementarity on the skill premia. In case of labor supply elasticities of around one, the augmenting influence of capital-skill complementarity on the skill premia has declined to a yearly impact of just 0.63 and 0.47 percent, respectively, for the above-mentioned skill premia.

\footnotetext{
${ }^{36}$ In the presence of capital-skill complementarity, the applied factor substitution elasticity between capital and high-skilled labor is set at 0.51 , that between the capital-skill input and medium-skilled labor is set at 1.33, and finally that between the intermediate input and low-skilled labor is set at 2.1 .
} 
To summarize, our interim results regarding the quantity effect state: The relatively high supply elasticities of low- and high-skilled labor in Germany had a quite strong alleviating impact on the German skill premia. Without these differentiated skill-specific labor supply elasticities, the increase in the German skill premium defined by the $9^{\text {th }}$ to $1^{\text {st }}$ decile limit of earnings would have been larger by about one third, while the one defined by the $9^{\text {th }}$ to $5^{\text {th }}$ decile limit of earnings would have been more than twice as large. Both changes refer to the analyzed period from 1991 to 2005. Accordingly, we find clear evidence that the quantity effect has countervailed the complementarity effect in the German case and that the quantity effect had a significant alleviating impact on the German skill premia.

Second, under inelastic labor supply the impact of capital-skill complementarity on the skill premia is enormous. The increase in the skill premia of the $9^{\text {th }}$ to $1^{\text {st }}$ and the $9^{\text {th }}$ to $5^{\text {th }}$ decile limit of earnings becomes almost three and five times larger, respectively, compared with the actual change in the skill premia. A steady increase in labor supply elasticities, however, counteracts the positive impact of capital-skill complementarity such that the increase in skill premia becomes less pronounced.

Third, in absolute terms, the influence of the quantity effect on the skill premia is much weaker (about 2.5 times smaller) compared with that of the complementarity effect.

\subsection{Sensitivity Analysis: Quantity Effect}

Finally, our last simulation comprises a sensitivity analysis with regard to the labor supply elasticities. We quantify the effect of a separate 1-percent increase in each labor supply elasticity. Our results are presented in Table 11.

Table 11: Sensitivity Analysis with regard to the Labor Supply Elasticities

\begin{tabular}{|c|c|c|c|c|c|c|}
\hline & \multicolumn{3}{|c|}{$\begin{array}{l}\text { Capital-Skill Complementarity } \\
\left(\sigma_{L}=2.1 ; \sigma_{M}=1.33 ; \sigma_{H}=0.51\right)\end{array}$} & \multicolumn{3}{|c|}{$\begin{array}{l}\text { No Capital-Skill Complementarity } \\
\left(\sigma_{L}=\sigma_{M}=\sigma_{H}=1.0\right)\end{array}$} \\
\hline & $\varepsilon_{L}: 0.89$ & $\varepsilon_{M}: 0.25$ & $\varepsilon_{H}: 0.8$ & $\varepsilon_{L}: .0 .89$ & $\varepsilon_{M}: 0.25$ & $\varepsilon_{H}: 0.8$ \\
\hline & $\rightarrow 0.899$ & $\rightarrow 0.253$ & $\rightarrow 0.808$ & $\rightarrow 0.899$ & $\rightarrow 0.253$ & $\rightarrow 0.808$ \\
\hline$\Delta \mathrm{D} 9 / \mathrm{D} 1$ & 12.23 & 12.21 & 12.10 & 0.53 & 0.48 & 0.44 \\
\hline$(\Delta$ in $\%)$ & $(+0.30)$ & $(+0.12)$ & $(-0.81)$ & $(+9.52)$ & $(+0.06)$ & $(-9.26)$ \\
\hline$\Delta \mathrm{D} 9 / \mathrm{D} 5$ & 5.79 & 5.81 & 5.68 & -4.33 & -4.30 & -4.37 \\
\hline$(\Delta$ in $\%)$ & $(-0.04)$ & $(+0.36)$ & $(-1.87)$ & $(-0.01)$ & $(-0.71)$ & $(+1.05)$ \\
\hline$\Delta \mathrm{D} 5 / \mathrm{D} 1$ & 6.09 & 6.05 & 6.07 & 5.07 & 4.99 & 5.03 \\
\hline$(\Delta$ in $\%)$ & $(+0.35)$ & $(-0.30)$ & $(-0.08)$ & $(+0.96)$ & $(-0.67)$ & $(-0.07)$ \\
\hline$\Delta L_{L}$ & -0.68 & -0.73 & -0.73 & 3.08 & 3.02 & 3.03 \\
\hline$\Delta L_{M}$ & -3.33 & -3.31 & -3.34 & -1.90 & 1.88 & -1.91 \\
\hline$\Delta L_{H}$ & 8.23 & 8.22 & 8.29 & 2.54 & 2.53 & 2.58 \\
\hline
\end{tabular}

Under CSC: $\Delta$ in D9/D1, D9/D5, D5/D1: 12.2, 5.79, 6.07; $\Delta$ in $L_{L}, L_{M}, L_{H}$ : -0.72, -3.32, 8.24

No CSC: $\Delta$ in D9/D1, D9/D5, D5/D1: 0.48, -4.33, 5.02; $\Delta$ in $L_{L}, L_{M}, L_{H}: 3.04,-1.90,2.55$

Source: Own calculations.

In the presence of capital-skill complementarity, a 1-percent increase in the labor supply elasticity of low-skilled labor has a small positive impact on the skill premia defined by the $9^{\text {th }}$ to $1^{\text {st }}$ and the $5^{\text {th }}$ to $1^{\text {st }}$ decile limit of earnings. The latter increases by 0.3 and 0.35 percent, respectively. The rationale for the observed variation in skill premia is based on the increased 
abundance of low-skilled labor (as a consequence of the larger supply elasticity), which exerts some downward pressure on the wage rate of the low-skilled.

A 1-percent increase in the labor supply elasticity of medium-skilled labor results in an increase by 0.36 percent in the skill premium of the $9^{\text {th }}$ to $5^{\text {th }}$ decile limit of earnings while that of the $5^{\text {th }}$ to $1^{\text {st }}$ decile limit of earnings falls by 0.3 percent. These variations in skill premia are straightforward effects resulting from an increased supply and therewith a lower wage rate of the medium-skilled.

Finally, a 1-percent increase in the labor supply elasticity of high-skilled labor reduces both the skill premia of the $9^{\text {th }}$ to $1^{\text {st }}$ and the $9^{\text {th }}$ to $5^{\text {th }}$ decile limit of earnings. The former declines by about 0.8 percent and the latter by almost 2 percent. The explanation for this finding is obvious and follows the above-mentioned lines of arguments.

In case we disregard capital-skill complementarity (right part of Table 11), a marginal change in labor supply elasticities has a much more pronounced impact throughout. This is particularly true for the skill premium defined by the $9^{\text {th }}$ to $1^{\text {st }}$ decile limit of earnings. All variations in the sensitivity analysis also refer to the 15-year period from 1991 to 2005.

\section{Conclusion}

In this paper we estimate the quantitative importance of capital-skill complementarity and endogenous skill-specific labor supply for wage inequality in Germany. Our simulation results are derived using a dynamic computable general equilibrium (CGE) model in the spirit of AuerbachKotlikoff (1987). The methodological contribution of our dynamic CGE model refers to the three-level constant elasticity of substitution (CES) production function using capital, and low-, medium-, and high-skilled labor as input factors as well as to the endogenous labor supply of each skill category. The modeling approach enables us to provide a detailed quantitative analysis on the isolated effects of capital-skill complementarity and differentiated skill-specific labor supply elasticities on the emerging skill premia as defined by the $9^{\text {th }}$ to $1^{\text {st }}$, the $9^{\text {th }}$ to $5^{\text {th }}$, and the $5^{\text {th }}$ to $1^{\text {st }}$ decile limit of earnings. In particular, the endogenous supply of the different labor skill categories allows us to separate the influence of capital-skill complementarity from the quantity effect, i.e., the impact resulting from the differentiated skill-specific labor supply elasticities on the various skill premia. This feature constitutes the major contribution of our study in addition to the detailed analysis in the evolution of skill premia, since nearly all existing papers in the literature just distinguish between low- and high-skilled labor (for instance, see Bound and Johnson 1992, Duffy et al. 2003, Goldin and Katz 1998, Krussel et al. 2000, Lindquist 2005, Papageorgiou and Chmelarova 2005, or Topel 1997). ${ }^{37}$

The simulation results confirm our conjecture that the complementarity or demand side effect has a particularly strong positive impact on the skill premia of the high-skilled while the quantity or supply side effect counteracts the complementarity effect and exerts a downward pressure on the skill premium of the high-skilled. Specifically, the demand side effect, i.e. capital-skill complementarity as confirmed in the empirical literature, ${ }^{38}$ has a quite substantial influence and raises the skill premium of the $9^{\text {th }}$ to $1^{\text {st }}$ and the $9^{\text {th }}$ to $5^{\text {th }}$ decile limit of earnings by more than

\footnotetext{
${ }^{37}$ The distinction among low-, medium-, and high-skilled labor is of particular importance when analyzing wage inequality in Germany, because low- and high-skilled labor cover only 15 and 27 percent, respectively, of the total German labor force.

${ }^{38}$ See Krussel et al. (2000) or Lindquist (2005), for instance.
} 
1.0 and 0.8 percent per year, respectively. The impact on the skill premium of the $5^{\text {th }}$ to $1^{\text {st }}$ decile limit of earnings amounts to 0.22 percent per year

Regarding the quantity or supply side effect, we find clear evidence that the prevailing constellation of skill-specific labor supply elasticities in Germany has a quite strong alleviating impact on the skill premia of the German high-skilled. In a world with non-differentiated labor supply elasticities, the skill premium of the $9^{\text {th }}$ to $1^{\text {st }}$ decile limit of earnings would have been larger by about one third while that of the $9^{\text {th }}$ to $5^{\text {th }}$ decile limit of earnings would have been more than twice as large. On a yearly basis, the alleviating impact that emanates from the differentiated skill-specific labor supply elasticities amounts to almost 0.3 and 0.45 percent for the skill premia defined by the $9^{\text {th }}$ to $1^{\text {st }}$ and the $9^{\text {th }}$ to $5^{\text {th }}$ decile limit of earnings, respectively. Contrary to that, the skill premium of the $5^{\text {th }}$ to $1^{\text {st }}$ decile limit of earnings increases by 0.18 percent per year due to the prevailing constellation of skill-specific labor supply elasticities.

Moreover, we find that the less elastic the labor supply elasticities are, the larger is the impact of capital-skill complementarity on skill premia. For the case of inelastic labor supply, our model computes an increase in the skill premia of the $9^{\text {th }}$ to $1^{\text {st }}$ and the $9^{\text {th }}$ to $5^{\text {th }}$ decile limit of earnings that are almost three and five times larger, respectively, over the 15-year period from 1999 to 2005 as compared with the actual values. ${ }^{39}$ Finally we state that even though both the complementarity and the quantity effects are antagonists, the complementarity effect has a much stronger (about 2.5 times larger) impact on the skill premia compared with the quantity effect.

An interesting question for further research relates to the influence of personal income taxes on individual labor supply and therewith on the quantity effect. In the presence of a progressive personal income tax system as it exists in almost all industrialized countries, the major tax burden levied on the high-skilled ought to have a strong (negative) impact on the labor supply decision of this particular skill group. Therefore, a plausible conjecture still to be approved claims that a progressive personal income tax system might have an alleviating impact on the observed quantity effect and hence enforces a further divergence in skill-specific wage rates, as already attested to in case of capital-skill complementarity.

\section{Appendix}

If we set each skill-specific labor supply elasticity close to zero and redo our sensitivity analysis carried out in section 3.2, we find that the changes in the skill premia of the $9^{\text {th }}$ to $1^{\text {st }}$ and the $9^{\text {th }}$ to $5^{\text {th }}$ decile limit of earnings are about three and five times larger, respectively, compared with the actual changes occurring under "normal" labor supply (see also the results presented in Table 8). However, an isolated 1-percent variation in one of the substitution elasticities $\sigma_{i}$, $i \in\{L, M, H\}$ has not necessarily a larger impact on the percentage change of the respective skill premia compared with the results derived under "normal" labor supply.

\footnotetext{
${ }^{39}$ Under inelastic labor supply, an isolated increase in one of the substitution elasticities does not, however, necessarily lead to a larger variation in the skill premia as compared with elastic labor supply. Thus, the magnitude of the labor supply elasticities affects just the absolute size of the increase in the skill premia, but not the impact resulting from a (marginal) variation in behavioral elasticities (see also Table A1 in the Appendix).
} 
Table A1: Sensitivity Analysis with regard to the Substitution Elasticities

\begin{tabular}{ccccccc}
\hline \hline & \multicolumn{3}{c|}{ Actual Labor Supply } & \multicolumn{3}{c}{$\begin{array}{c}\text { Inelastic Labor Supply } \\
\left(\varepsilon_{L}=\varepsilon_{M}=\varepsilon_{H}=0.01\right)\end{array}$} \\
\cline { 2 - 7 } & $\sigma_{L}: 2.1$ & $\sigma_{M}: 1.33$ & $\sigma_{H}: 0.51$ & $\sigma_{L}: 2.1$ & $\sigma_{M}: 1.33$ & $\sigma_{H}: 0.51$ \\
& $\rightarrow 2.121$ & $\rightarrow 1.343$ & $\rightarrow 0.515$ & $\rightarrow 2.121$ & $\rightarrow 1.343$ & $\rightarrow 0.515$ \\
\cline { 2 - 7 }$\Delta$ D9/D1 & 12.3 & 12.2 & 12.10 & 36.3 & 36.2 & 35.6 \\
$(\Delta$ in \% $)$ & $(+0.43)$ & $(+0.18)$ & $(-0.92)$ & $(+0.29)$ & $(+0.16)$ & $(-1.57)$ \\
$\Delta$ D9/D5 & 5.79 & 5.93 & 5,70 & 30.24 & 30.5 & 29.7 \\
$(\Delta$ in \%) & $(-0.01)$ & $(+2.34)$ & $(-1.67)$ & $(0.00)$ & $(+0.71)$ & $(-1.89)$ \\
$\Delta$ D5/D1 & 6.12 & 5.96 & 6,06 & 4.64 & 4.44 & 4.56 \\
$(\Delta$ in \% $)$ & $(+0.82)$ & $(-1.88)$ & $(-0.10)$ & $(+1.75)$ & $(-2.78)$ & $(-0.10)$ \\
\hline
\end{tabular}

Variation in skill premia, D9/D1, D9/D5, D5/D1 under actual labor supply: 12.2, 5.8, 6.1.

Variation in skill premia, D9/D1, D9/D5, D5/D1 under inelastic labor supply: 36.2, 30.2, 4.56.

Source: Own calculations.

For instance, under inelastic labor supply a 1-percent increase in the elasticity of substitution of low-skilled labor raises the skill premium of the $9^{\text {th }}$ to $1^{\text {st }}$ decile limit of earnings by less than 0.3 percent over the period from 1991 to 2005, whereas in the case of normal labor supply the variation in this skill premium amounts to more than 0.4 percent. However, the increase in the skill premium of the $5^{\text {th }}$ to $1^{\text {st }}$ decile limit of earnings amounts to almost 1.8 percent under inelastic labor supply while it amounts to just 0.8 percent in the case of elastic labor supply.

Furthermore, under inelastic labor supply, a 1-percent increase in the elasticity of substitution for medium-skilled labor raises the skill premium of the $9^{\text {th }}$ to $5^{\text {th }}$ decile limit of earnings by just 0.7 percent, while its increase amounts to 2.3 percent when actual labor supply elasticities are applied. The reverse is true for the skill premium of the $5^{\text {th }}$ to $1^{\text {st }}$ decile limit of earnings: it diminishes by almost 2.8 percent under inelastic labor supply but by only 1.9 percent under elastic labor supply.

Only the variation in the substitution elasticity of high-skilled labor results in a strictly larger increase of the skill premia under inelastic labor supply.

\section{References}

[1] Auerbach A.J. and Laurence J. Kotlikoff (1987): Dynamic Fiscal Policy, Cambridge.

[2] Bandholz H., Flaig, G and J. Mayr (2005): "Wachstum und Konjunktur in OECD Ländern: Eine langfrisitge Perspektive," ifo Schnelldienst 58/4, pp. 28-36.

[3] Bound, J. and G. Johnson (1992): "Changes in the Structure of Wages in the 1980s: An Evaluation of Alternative Explanations," American Economic Review, 82, 371-392.

[4] Chirinko, R.S., S.M. Fazzari and A.P. Meyer (1999): "How Responsive is Business Capital Formation to Its User Cost? An Exploration with Micro Data," Journal of Public Economics 74, pp. 53-80.

[5] Cummins, J.G., Hassett K.A. and G.R. Hubbard (1996): "Tax Reform and Investment: A Cross-Country Comparison," Journal of Public Economics 62, pp. 237-273. 
[6] Destatis, Statistisches Bundesamt (1994): Statistisches Jahrbuch 1994 für die Bundesrepublik Deutschland, Wiesbaden.

[7] Destatis, Statistisches Bundesamt (2006): Statistisches Jahrbuch 2006 für die Bundesrepublik Deutschland, Wiesbaden.

[8] Destatis, Statistisches Bundesamt (2006a): Pressemiteilung 366 vom 7.09.2006, "Capital endowment of workers," Wiesbaden.

[9] Duffy, J., Papageorgiou, C. and F. Perez-Sebastian (2004): "Capital-Skill Complementarity? Evidence from a Panel of Countries," Review of Economics and Statistics 86, $327-244$.

[10] FAllon P.R. and R. LAyard (1975): "Capital-Skill Complementarity, Income Distribution, and Output Accounting," Journal of Political Economy, 83, 279-302.

[11] Fenr, H. (1999): Welfare Effects of Dynamic Tax Reforms, Tübingen: Mohr-Siebeck.

[12] Feldstein, M. (2005): "Structural Reform of Social Security," Journal of Economic Perspectives, $19 / 2$, pp. $33-55$

[13] FitzRoy, F. and M. Funke (1995): "Capital-Skill Complementarity in West German Manufacturing," Empirical Economics 20, 651-665.

[14] Flaig, G. (1988): "Einkommen, Zinssatz und Inflation - Ein Beitrag zur Erklärung von Konsumwachstumsschwankungen," in: G. Bombach, B. Gahlen, A.E. Ott, (eds.), Geldtheorie und Geldpolitik, Tübinge: Mohr Siebeck, pp. 291-314.

[15] German Central Bank (1995): "Das Produktionspotential in Deutschland und seine Bestimmungsfaktoren," Monatsbericht 47/ 8, pp. 41-57.

[16] Gernandt, J. and F. Pfeiffer (2006): "Rising Wage Inequality in Germany," $Z E W$ Discussion Papers 06-19.

[17] Griliches, Z. (1969): "Capital-Skill Complementarity," Review of Economics and Statistics, 51/4, 465-68.

[18] Goldin C. and L. F. Katz (1998): "The Origins of Technology-Skill Complementarity," Quarterly Journal of Economics, 113, 693-732.

[19] Hammermesh, D. (1993): Labor Demand, Princeton: Princeton University Press.

[20] Jorgenson, D. W. and K.-Y. Yun (2001): Lifting the Burden: Tax Reform, The Cost of Capital, and U.S. Economic Growth, Cambridge: MIT Press.

[21] KeuschnigG, C. and M. Dietz (2004), "A Swiss Dual Income Tax For More Neutrality in Company Taxation," Swiss Journal of Economics and Statistics 140, pp. 483-519.

[22] Krusell, P., Ohanian, L., Rois-Rull, J.-V. and G. Violante (2000): "CapitalSkill Complementarity and Inequality: A Macroeconomic Analysis," Econometrica, 68/5, 1029-1053.

[23] Lindquist, M. J.(2005): "Capital-Skill Complementarity and Inequality in Sweden," Scandinavian Journal of Economics, 107/4, 711-735. 
[24] Machin, S. and J. Van Reenen (1998): "Technology and Changes in skill Structure: Evidence from Seven OECD Countries," Quarterly Journal of Economics, 113/4, 1215-1244.

[25] OECD (2007): Employment Outlook 2007, OECD, Paris.

[26] Papageorgiou, C. and V. Chmelarova (2005): "Nonlinearities in Capital-Skill Complementarity," Journal of Economic Growth, 10, 59-89.

[27] Roskamp, K.A. (1977): "Labor Productivity and the Elasticity of Factor Substitution in West German Industries," The Review of Economics and Statistics 59, pp. 366-371.

[28] Stimmelmayr, M. (2007): Fundamental Capital Income Tax Reforms: Discussion and Simulation using ifoMOD, Mohr Siebeck, Tübingen.

[29] Topel, R.H. (1997): "Factor Proportions and Relative Wages: The Supply-Side Determinants of Wage Inequality," Journal of Economic Perspectives 11/2, 55-47.

[30] Valkonen, T. (1999): The Finnish Corporate and Capital Income Tax Reform: A General Equilibrium Approach, ETLA, Helsinki.

[31] Whited, T.N. (1994): "Problems with Identifying Adjustment Costs From Regressions of Investment on Q," Economic Letters 46, pp. 327-332. 


\section{CESifo Working Paper Series}

for full list see www.cesifo-group.org/wp

(address: Poschingerstr. 5, 81679 Munich, Germany, office@cesifo.de)

2741 Yan Dong and John Whalley, A Third Benefit of Joint Non-OPEC Carbon Taxes: Transferring OPEC Monopoly Rent, August 2009

2742 Valentina Bosetti, Carlo Carraro and Massimo Tavoni, Climate Change Mitigation Strategies in Fast-Growing Countries: The Benefits of Early Action, August 2009

2743 Christina Felfe, The Willingness to Pay for Job Amenities: Evidence from Mothers' Return to Work, August 2009

2744 Jörg Franke, Christian Kanzow, Wolfgang Leininger and Alexandra Väth, Effort Maximization in Asymmetric N-Person Contest Games, August 2009

2745 Bruno S. Frey and Paolo Pamini, Making World Heritage Truly Global: The Culture Certificate Scheme, August 2009

2746 Frank N. Caliendo, Is Social Security behind the Collapse of Personal Saving?, August 2009

2747 Caterina Liesegang and Marco Runkel, Corporate Income Taxation of Multinationals and Fiscal Equalization, August 2009

2748 Chrysovalantou Milliou and Apostolis Pavlou, Upstream Horizontal Mergers and Efficiency Gains, August 2009

2749 Rüdiger Pethig and Christian Wittlich, Interaction of Carbon Reduction and Green Energy Promotion in a Small Fossil-Fuel Importing Economy, August 2009

2750 Kai Carstensen, Oliver Hülsewig and Timo Wollmershäuser, Monetary Policy Transmission and House Prices: European Cross-country Evidence, August 2009

2751 Olaf Posch, Explaining Output Volatility: The Case of Taxation, August 2009

2752 Beatrice Scheubel, Daniel Schunk and Joachim Winter, Don't Raise the Retirement Age! An Experiment on Opposition to Pension Reforms and East-West Differences in Germany, August 2009

2753 Daniel G. Arce, Dan Kovenock and Brian Roberson, Suicide Terrorism and the Weakest Link, August 2009

2754 Mario Larch and Wolfgang Lechthaler, Comparative Advantage and Skill-Specific Unemployment, August 2009

2755 Horst Raff and Nicolas Schmitt, Buyer Power in International Markets, August 2009 
2756 Seppo Kari, Hanna Karikallio and Jukka Pirttilä, The Impact of Dividend Taxation on Dividends and Investment: New Evidence Based on a Natural Experiment, August 2009

2757 Mirco Tonin and Michael Vlassopoulos, Disentangling the Sources of Pro-social Behavior in the Workplace: A Field Experiment, August 2009

2758 Nicole Grunewald and Inmaculada Martínez-Zarzoso, Driving Factors of Carbon Dioxide Emissions and the Impact from Kyoto Protocol, August 2009

2759 Yu-Fu Chen and Michael Funke, Booms, Recessions and Financial Turmoil: A Fresh Look at Investment Decisions under Cyclical Uncertainty, August 2009

2760 Jan-Egbert Sturm and Jakob de Haan, Does Central Bank Communication really Lead to better Forecasts of Policy Decisions? New Evidence Based on a Taylor Rule Model for the ECB, August 2009

2761 Larry Karp, Sacrifice, Discounting and Climate Policy: Five Questions, August 2009

2762 Marianna Belloc and Samuel Bowles, International Trade, Factor Mobility and the Persistence of Cultural-Institutional Diversity, August 2009

2763 Charles Noussair and Fangfang Tan, Voting on Punishment Systems within a Heterogeneous Group, August 2009

2764 Birgit Bednar-Friedl and Karl Farmer, Internationally Coordinated Emission Permit Policies: An Option for Withdrawers from the Kyoto Protocol?, August 2009

2765 Pierre M. Picard and David E. Wildasin, Labor Market Pooling, Outsourcing and Labor Contracts, August 2009

2766 Stefan Voigt and Lorenz Blume, The Economic Effects of Federalism and Decentralization - A Cross-Country Assessment, August 2009

2767 David S. Jacks, Christopher M. Meissner and Dennis Novy, Trade Booms, Trade Busts, and Trade Costs, August 2009

2768 Mario Jametti and Thomas von Ungern-Sternberg, Hurricane Insurance in Florida, August 2009

2769 Alessandro Balestrino, Kind of Black: The Musicians' Labour Market in Italy, August 2009

2770 Yosr Abid Fourati and Cathal O’Donoghue, Eliciting Individual Preferences for Pension Reform, August 2009

2771 Christian Breuer and Chang Woon Nam, VAT on Intra-Community Trade and Bilateral Micro Revenue Clearing in the EU, August 2009

2772 Choudhry Tanveer Shehzad, Jakob De Haan and Bert Scholtens, Growth and Earnings Persistence in Banking Firms: A Dynamic Panel Investigation, August 2009 
2773 Erdal Yalcin, Uncertain Productivity Growth and the Choice between FDI and Export, August 2009

2774 Klaus Abberger, Wolfgang Nierhaus and Shynar Shaikh, Findings of the Signal Approach for Financial Monitoring in Kazakhstan, September 2009

2775 Sascha O. Becker, Francesco Cinnirella and Ludger Woessmann, The Trade-off between Fertility and Education: Evidence from before the Demographic Transition, September 2009

2776 Thomas Aronsson and Erkki Koskela, Optimal Income Taxation, Outsourcing and Policy Cooperation in a Dynamic Economy, September 2009

2777 Joel Slemrod, Old George Orwell Got it Backward: Some Thoughts on Behavioral Tax Economics, September 2009

2778 Cagri Seda Kumru and Athanasios C. Thanopoulos, Social Security Reform and Temptation, September 2009

2779 Alessandro Bucciol and Roel M. W. J. Beetsma, Inter- and Intra-generational Consequences of Pension Buffer Policy under Demographic, Financial and Economic Shocks, September 2009

2780 Eduardo Strube and Marcelo Resende, Complementarity of Innovation Policies in the Brazilian Industry: An Econometric Study, September 2009

2781 Henry Tulkens and Vincent van Steenberghe, "Mitigation, Adaptation, Suffering": In Search of the Right Mix in the Face of Climate Change, September 2009

2782 Maria L. Loureiro, Anna Sanz-de-Galdeano and Daniela Vuri, Smoking Habits: Like Father, Like Son, Like Mother, Like Daughter, September 2009

2783 Momi Dahan, Tehila Kogut and Moshe Shalem, Do Economic Policymakers Practice what they Preach? The Case of Pension Decisions, September 2009

2784 Eytan Sheshinski, Uncertain Longevity and Investment in Education, September 2009

2785 Nannette Lindenberg and Frank Westermann, How Strong is the Case for Dollarization in Costa Rica? A Note on the Business Cycle Comovements with the United States, September 2009

2786 Leif Danziger, Noncompliance and the Effects of the Minimum Wage on Hours and Welfare in Competitive Labor Markets, September 2009

2787 Gerlinde Fellner, Rupert Sausgruber and Christian Traxler, Testing Enforcement Strategies in the Field: Legal Threat, Moral Appeal and Social Information, September 2009

2788 Gabriel J. Felbermayr, Mario Larch and Wolfgang Lechthaler, Unemployment in an Interdependent World, September 2009 
2789 Sebastian G. Kessing, Federalism and Accountability with Distorted Election Choices, September 2009

2790 Daniel Gros, Global Welfare Implications of Carbon Border Taxes, September 2009

2791 Louis N. Christofides, Michael Hoy and Ling Yang, The Gender Imbalance in Participation in Canadian Universities (1977-2005), September 2009

2792 Jan K. Brueckner and Robert W. Helsley, Sprawl and Blight, September 2009

2793 Vidar Christiansen and Stephen Smith, Externality-correcting Taxes and Regulation, September 2009

2794 John Beirne, Guglielmo Maria Caporale, Marianne Schulze-Ghattas and Nicola Spagnolo, Global and Regional Spillovers in Emerging Stock Markets: A Multivariate GARCH-in-mean Analysis, September 2009

2795 Rüdiger Pethig and Frieder Kolleß, Asymmetric Capital-Tax Competition, Unemployment and Losses from Capital Market Integration, September 2009

2796 Ngo Van Long, Horst Raff and Frank Stähler, Innovation and Trade with Heterogeneous Firms, September 2009

2797 Margit Osterloh and Bruno S. Frey, Research Governance in Academia: Are there Alternatives to Academic Rankings?, September 2009

2798 Thiess Buettner and Clemens Fuest, The Role of the Corporate Income Tax as an Automatic Stabilizer, September 2009

2799 Annette Alstadsæter, Measuring the Consumption Value of Higher Education, September 2009

2800 Peter Friedrich, Chang Woon Nam and Janno Reiljan, Local Fiscal Equalization in Estonia: Is a Reform Necessary?, September 2009

2801 Evžen Kočenda and Jan Hanousek, State Ownership and Control in the Czech Republic, September 2009

2802 Michael Stimmelmayr, Wage Inequality in Germany: Disentangling Demand and Supply Effects, September 2009 